\title{
Long-term in situ observations of biomass burning aerosol at a high altitude station in Venezuela - sources, impacts and interannual variability
}

\author{
T. Hamburger ${ }^{1, *}$, M. Matisāns ${ }^{1}$, P. Tunved ${ }^{1}$, J. Ström ${ }^{1}$, S. Calderon ${ }^{2}$, P. Hoffmann ${ }^{2}$, G. Hochschild ${ }^{3}$, J. Gross ${ }^{3}$, \\ T. Schmeissner ${ }^{4}$, A. Wiedensohler ${ }^{4}$, and R. Krejci ${ }^{1,5}$ \\ ${ }^{1}$ Department of Applied Environmental Science (ITM), Stockholm University, 10691 Stockholm, Sweden \\ ${ }^{2}$ Universidad de Los Andes, Merida 5101, Venezuela \\ ${ }^{3}$ Karlsruhe Institute of Technology, Institute for Meteorology and Climate Research (ASF), 76344 Eggenstein-Leopoldshafen, \\ Germany \\ ${ }^{4}$ Leibniz Institute for Tropospheric Research (TROPOS), 04318 Leipzig, Germany \\ ${ }^{5}$ Division of Atmospheric Sciences Department of Physics, University of Helsinki, 00014 Helsinki, Finland \\ *now at: NILU - Norwegian Institute for Air Research, P.O. Box 100, 2027 Kjeller, Norway
}

Correspondence to: T. Hamburger (thomas.hamburger@nilu.no)

Received: 30 April 2013 - Published in Atmos. Chem. Phys. Discuss.: 17 May 2013

Revised: 26 August 2013 - Accepted: 26 August 2013 - Published: 7 October 2013

\begin{abstract}
First long-term observations of South American biomass burning aerosol within the tropical lower free troposphere are presented. The observations were conducted between 2007 and 2009 at a high altitude station (4765 m a.s.l.) on the Pico Espejo, Venezuela. Sub-micron particle volume, number concentrations of primary particles and particle absorption were observed. Orographic lifting and shallow convection leads to a distinct diurnal cycle at the station. It enables measurements within the lower free troposphere during night-time and observations of boundary layer air masses during daytime and at their transitional regions. The seasonal cycle is defined by a wet rainy season and a dry biomass burning season. The particle load of biomass burning aerosol is dominated by fires in the Venezuelan savannah. Increases of aerosol concentrations could not be linked to long-range transport of biomass burning plumes from the Amazon basin or Africa due to effective wet scavenging of particles. Highest particle concentrations were observed within boundary layer air masses during the dry season. Ambient sub-micron particle volume reached $1.4 \pm 1.3 \mu^{3} \mathrm{~cm}^{-3}$, refractory particle number concentrations (at $300^{\circ} \mathrm{C}$ ) $510 \pm 420 \mathrm{~cm}^{-3}$ and the absorption coefficient $0.91 \pm 1.2 \mathrm{Mm}^{-1}$. The respective concentrations were lowest within the lower free troposphere during the wet season and averaged at $0.19 \pm 0.25 \mu \mathrm{m}^{3} \mathrm{~cm}^{-3}$,
\end{abstract}

$150 \pm 94 \mathrm{~cm}^{-3}$ and $0.15 \pm 0.26 \mathrm{Mm}^{-1}$. A decrease of particle concentrations during the dry seasons from 2007-2009 could be connected to a decrease in fire activity in the wider region of Venezuela using MODIS satellite observations. The variability of biomass burning is most likely linked to the El Niño-Southern Oscillation (ENSO). Low biomass burning activity in the Venezuelan savannah was observed to follow La Niña conditions, high biomass burning activity followed El Niño conditions.

\section{Introduction}

Atmospheric aerosol particles directly scatter and absorb sunlight (e.g. Haywood and Boucher, 2000) or indirectly perturb the solar radiation by changing the formation and life cycle of clouds (e.g. Lohmann and Feichter, 2005). Thus, knowledge on their physical and chemical properties and temporal and spatial variability is of major importance when investigating the earth-climate system. Relative to greenhouse gases, particles in the atmosphere can be considered as a rather short-lived radiatively active species. Their properties feature a high variability in space and time. This makes the quantitative estimate of their climatic effects 
highly uncertain (Andreae et al., 2005). Recent and ongoing work helps to reduce these uncertainties (e.g. Forster et al., 2007; Myhre, 2009; Shindell et al., 2009, and references therein).

Within the present work we focus on observations of light absorbing aerosol particles within the tropical planetary boundary layer and lower free troposphere. Absorbing particles, as aerosol particles in general, reduce the incoming solar radiation on the surface and thus lead to a surface cooling. In addition, the absorbing particles heat the air at upper levels due to absorption of solar radiation. Hence, they alter the vertical temperature profile, latent heat fluxes, atmospheric stability and large-scale convection (Menon et al., 2002). Absorbing aerosol particles may also decrease low level cumulus cloud cover by heating the upper boundary layer which reduces the ambient relative humidity (Ackerman et al., 2000).

The main absorbing aerosol particle in the atmosphere is black carbon (BC). Its contribution to global warming may be substantial (Chameides and Bergin, 2002). BC is the main absorbing component of soot next to several other absorbing condensed organic components (Andreae and Gelencsér, 2006; Ramanathan and Carmichael, 2008). Soot is produced through incomplete combustion of biomass, coal, and diesel fuel. The radiative and chemical properties of soot and its content of BC crucially depend on the source of the fuel (Chameides and Bergin, 2002) and the efficiency of the combustion process (Novakov et al., 2003). The resulting properties of the soot particles are defined by the mainly unknown shape (van Poppel et al., 2005). In addition to their radiative impacts, soot particles also play a large role in air quality and human health issues (Shindell et al., 2012).

One of the dominating sources of soot is biomass burning, that is, open burning of forest, savannah and agricultural areas. Biomass burning produces $\sim 40 \%$ of the global BC emissions (Bond et al., 2004). Model simulations using in situ observations of brown clouds which result from biomass burning in Asia showed that these clouds may contribute as much as the recent increase of anthropogenic greenhouse gases to regional lower atmospheric warming trends (Ramanathan et al., 2007). Large radiative impacts were observed above land in the biomass burning areas of Africa and South America and over the ocean downwind from the biomass burning regions (Bellouin et al., 2005). Biomass burning in South America itself contributes $30 \%$ to the global total biomass burning activities (Rissler et al., 2006) and 20-25\% to global BC emissions (Koch et al., 2007; Bond et al., 2004).

Next to biomass burning in the Amazon region, which is a major source of pollution in the tropical Southern Hemisphere (Streets et al., 2004; Edwards et al., 2006), biomass burning in the savannah region of northern South America contributes to a considerable amount to the pollution level in the tropical Northern Hemisphere (Hao and Liu, 1994). Most fires in the savannah region are of anthropogenic ori- gin, for example, to control weeds and pest, to prevent litter accumulation, or to accelerate nutrient cycling (Sanhueza et al., 1999). In situ observations in the savannah region of the Venezuelan low lands proved a substantial contribution of biomass burning to the particle load at remote sites (Sanhueza et al., 1987; Morales et al., 1990). Biomass burning plumes originating from this area were observed at high altitudes during several airborne field campaigns (e.g. Andreae et al., 2001). However, to the best of our knowledge, there exist no long-term in situ data of air masses effected by biomass burning in northern South America.

In this paper we provide the analysis of in situ observations which were conducted at a high altitude station (4765 ma.s.1.) downwind from the savannah plains of Venezuela. The observations were conducted between 20072009 and comprise two rainy seasons and three dry seasons. Thus, we provide the first long-term in situ observations of soot particles from biomass burning mixing into the lower free tropical troposphere above South America.

\section{Methods}

\subsection{Measurement site}

The Pico Espejo Atmospheric Research Station Alexander von Humboldt is located at $8^{\circ} 31^{\prime} \mathrm{N}, 71^{\circ} 3^{\prime} \mathrm{W}$ at an altitude of $4765 \mathrm{~m}$ a.s.l. (Calderón et al., 2008; Schmeissner et al., 2011) close to Venezuela's highest mountain, Pico Bolívar (4981 ma.s.1.). The mountain is part of the north-eastern branch of the Andes. The mountain range has a width of $\sim 100 \mathrm{~km}$ at the location of the observation site. The measurement station was rebuilt in 2001 by the Universidad de los Andes (ULA) in collaboration with the University of Karlsruhe and the Research Centre Karlsruhe (FZK), Germany, which in the meantime have merged into the Karlsruhe Institute of Technology (KIT). The station can be reached by the Mérida Cable Car which was closed to public use in 2008. The city of Mérida (1630 ma.s.l.) is located approximately $10 \mathrm{~km}$ north-west of the Pico Espejo and is the largest populated area in the closer vicinity with a population reaching almost 200000 inhabitants. The next densely populated urban areas and possible source regions of urban aerosol are the cities of San Cristóbal ( 600000$), 860$ m a.s.l., Venezuela, and Cúcuta ( $\sim 1.1 \mathrm{mio}), 320 \mathrm{~m}$ a.s.l., Colombia, both located $150 \mathrm{~km}$ to the south-west. The metropolitan area of Maracaibo ( $\sim 2.1 \mathrm{mio}$ ), $6 \mathrm{~m}$ a.s.l., Venezuela, is located $250 \mathrm{~km}$ to the north (Fig. 1). A vast tropical grassland plain (Los Llanos), which is mostly of agricultural use, extends to the south and south-east of the mountain range. This Venezuelan savannah is located between the Amazon forest in the south and the Caribbean Sea in the north. The climatological seasons in the region are defined by a rainy season from May to November and a dry season from December to April (Morales et al., 1990). Frequent biomass burning occurs in 


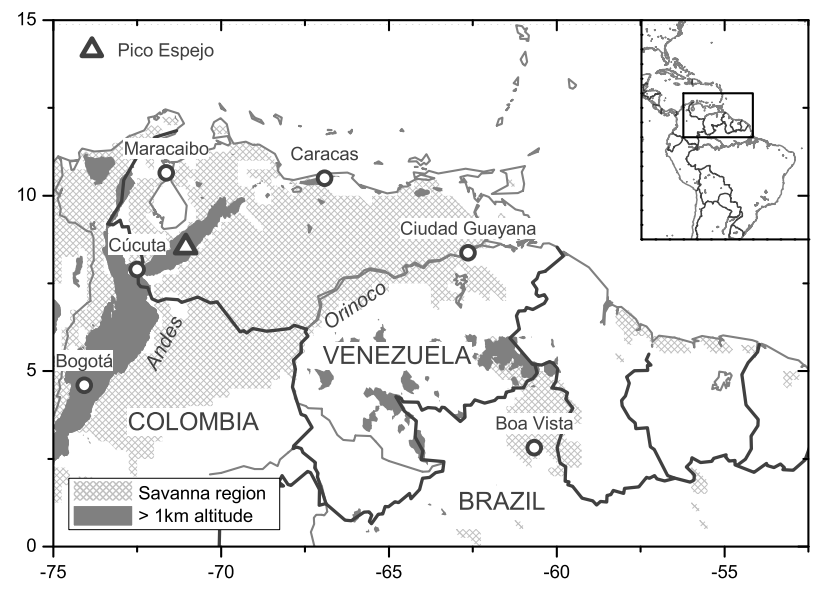

Fig. 1. Map of the northern part of South America. The triangle indicates the position of the Pico Espejo Atmospheric Research Station Alexander von Humboldt (4765 m a.s.1.) in Venezuela.

the end of the dry season mainly between March and May. The fires are located in the savannah region which reaches from the mountain ridge of the Andes in the west and follows the Orinoco river basin to the east (Rondón and Sanhueza, 1990). The prevailing wind direction is governed by the northern hemispheric Trade winds; most of the time the wind blows from ENE (Sanhueza et al., 1987). Hence, the Venezuelan savannah serves as an important source region of biomass burning aerosol upwind the measurement site. Source regions of marine aerosol are rather distant, with the Pacific $800 \mathrm{~km}$ to the west, the Caribbean $400 \mathrm{~km}$ to the north and the Atlantic more than $1000 \mathrm{~km}$ to the east.

\subsection{Instrumentation}

The aerosol instrumentation was provided by the Department of Applied Environmental Science (ITM), Stockholm University (see Schmeissner et al., 2011, for details). The aerosol was sampled through a $6 \mathrm{~m}$ long vertical inlet which was heated to $15^{\circ} \mathrm{C}$. The air reached the aerosol instrumentation at a relative humidity between 10-20\%. The aerosol inlet has a transmission efficiency close to $100 \%$ for submicron aerosol. The $50 \%$ cut-off diameter is $D_{50 \%} \sim 5-7 \mu \mathrm{m}$.

Ambient aerosol number size distributions were observed with a mobility particle size spectrometer type DMPS (custom-built Differential Mobility Particle Sizer). The DMPS was set to a size spectrum for particle diameters between $10 \mathrm{~nm}$ and $470 \mathrm{~nm}$. The DMPS system was operated with one Condensation Particle Counter (CPC) model 3010, TSI Inc. The analysis of the observed ambient aerosol number concentrations at the Pico Espejo was realized by Schmeissner et al. (2011) and can be found in the respective publication. A second CPC was used in combination with a Thermodenuder which heated the sampled aerosol to $300^{\circ} \mathrm{C}$. The volatile and semi-volatile aerosol compounds were evaporated before the sampled probe reached the second CPC. The thermodenuder was installed behind the Differential Mobility Analyser (DMA) of the DMPS. Hence, the upper cut-off diameter of the residual particles was limited by the diameter range of the DMPS.

The residual particles include primary aerosol as well as very low-volatile secondary organic compounds (Wehner et al., 2005; Häkkinen et al., 2012). The primary particles most commonly consist of dust, sea spray and soot. However, $\mathrm{BC}$ from combustion processes is the most abundant primary particle species in the observed size range from $10-470 \mathrm{~nm}$. Previous observations showed that particle size distributions resulting from vegetation fires have a mean geometric diameter of 120-230 nm. Particles on the larger end of the diameter range are associated with rather aged biomass burning plumes (days) and smaller diameters with fresh plumes (hours) (Janhäll et al., 2010). The size range of biomass burning particles falls into the size range of the observations presented here. However, the appearance of larger primary particles in the super-micrometre diameter range, such as sea salt or mineral dust, cannot be completely neglected due to long range transport (e.g. VanCuren et al., 2005; Ben-Ami et al., 2010; Hallar et al., 2011a).

The aerosol absorption coefficient $b_{\text {abs }}$ was measured by a filter based technique using a custom-build Particle Soot Absorption Photometer (PSAP). The PSAP measures the light extinction of aerosol particles at a wavelength of $\lambda=$ $525 \mathrm{~nm}$. The particle filters were mounted in a revolver like system allowing for automatic filter change. A transmission value of $\operatorname{Tr}=0.5$ was set as threshold for each filter change.

An automatic weather station detected standard meteorological parameters including pressure, temperature, relative humidity, wind speed and wind direction, and direct and diffuse radiation. In addition, two webcams were installed at the research station facing the northern and southern slopes of the Pico Espejo. The webcams saved pictures in $15 \mathrm{~min}$ intervals. A Photometric Ozone Analyser completed the instrumentation set-up. Results of the Ozone measurements can be found in Calderón et al. (2008).

The observations were carried out from March 2007 until May 2009. A routine check was performed every 5th day on average. All concentrations are given at ambient conditions. To convert from ambient to standard temperature and pressure $\left(T_{\mathrm{stp}}=273.15 \mathrm{~K}, p_{\mathrm{stp}}=1013.25 \mathrm{hPa}\right)$ use stp $=1.77( \pm 0.01) \mathrm{amb}$.

\subsection{Data analysis}

Break-up of cloud droplets on the aerosol inlet and subsequent sampling of the droplet particles can only be strong bias to the observations. Therefore, in-cloud data had to be removed. In-cloud sequences were determined using the webcam images and a cloud detection algorithm. The webcam used for cloud detection was facing towards the south-east. The horizon split the webcam images at approximately $40 \%$ 
from the bottom. The upper $60 \%$ of the images showed the sky. The Python Imaging Library (PIL) was used to detect the relative fraction of blue, grey, black or other pixels. Clear sky was defined if the upper $50 \%$ of the picture consisted of more than $75 \%$ blue pixels and the total amount of blue pixels was less than $60 \%$ to avoid incorrect imagery. If grey could be assigned to more than $90 \%$ of the total pixels the image was defined as an in-cloud image. Night-time was defined if more than $50 \%$ of the total pixels were black. The assigned in-cloud sequences had a median relative humidity of $\mathrm{RH} \sim 97 \%$. When no suitable webcam image was available - or during the night - all observations with $\mathrm{RH}>95 \%$ were marked as in-cloud sequences and the respective data were excluded for the subsequent analysis.

The data inversion method of the DMPS measurements is described in Schmeissner et al. (2011) and Wiedensohler et al. (2012). Schmeissner et al. (2011) note that $13 \%$ of the DMPS observations had to be excluded due to erroneous data. The particle volume concentration was calculated from the particle number size distributions assuming spherical particles. One has to keep in mind that the number size distribution was inverted using the mobility diameter (volume equivalent diameter in case of spherical particles). Depending on the real morphology of the observed particles, the assumption of a spherical shape might slightly overestimate the volume concentration. In the atmosphere, particles such as soot agglomerates are relatively compact if they have been in contact with water and the shape factor might be only slightly larger. One can assume that most biomass burning plumes reaching the observation site have been aged for several days. Additionally, condensation of secondary particulate matter on soot particles leads to an even more compact form (Zhang et al., 2008; Fu et al., 2012) which reduces the error created by the assumption of spherical particles.

The PSAP measurements were corrected following the correction schemes by Bond et al. (1999), Virkkula et al. (2005), and Virkkula (2010). The ambient DMPS size distribution was used to estimate the scattering coefficient for the scattering correction. The refractive index of Ammonium sulfate $(1.42 \pm 0.006)$ was applied. However, the upper cutoff diameter of the DMPS lies well below the upper cut-off diameter of the aerosol inlet. This may cause an underestimation of the scattering coefficient and therefore may result in an overestimation of the absorption coefficient $(\sim 10 \%)$. A distinctive decrease in the changing rate of the transmission was observed for $\operatorname{Tr}<0.7$ during the processing of the raw data. The reduced changing rate resulted in an underestimation of the calculated absorption coefficient at $\operatorname{Tr}<0.7$. Thus, the threshold value of the transmission was set to $\operatorname{Tr}=0.7$ to avoid bias induced by strongly polluted filters. In addition, $30 \%(\sim 155$ out of 510 days) of the PSAP data had to be excluded due to malfunction of the filter change procedure or malfunction of the recording of the sampled air flow through the PSAP instrument.
We resign to convert $b_{\mathrm{abs}}$ to the mass concentration of $\mathrm{BC}$, though $\mathrm{BC}$ dominates the absorption of light on the filter. The conversion of $b_{\mathrm{abs}}$ to $\mathrm{BC}$ mass relies on the mass absorption coefficient (MAC) which undergoes large variabilities depending on the optical properties of the sampled soot (Mertes et al., 2004; Bond and Bergstrom, 2006; Schwarz et al., 2008; Naoe et al., 2009; Yang et al., 2009). However, the lack of chemical information present does not allow for an accurate definition of MAC.

Applying the correction and the elimination of errors of the DMPS and PSAP raw data in combination with the exclusion of cloud data a total of $20 \%$ of the original PSAP raw data could be used for the following analysis. Nevertheless, the PSAP data covers all rainy and dry seasons which were observed.

The observations were divided into two distinct air masses that possibly reach the high altitude station: air masses of the lower free troposphere (LFT) and air masses from the boundary layer (BL). The separation was defined by using the typical diurnal cycle which could be observed at the site. It is described in Sect. 3.4. Measurements were assigned to the BL if they were observed between 10:00 and 23:00 local time (LT) and if the relative humidity (RH) did not reach below $65 \%$. All night-time data, along with daytime data at $\mathrm{RH}<65 \%$ were considered as observations within the LFT.

\subsection{Air mass transport analysis and satellite observations}

We used the well-known HYSPLIT trajectory model (Draxler, 1999) to analyse the history of the air masses that reach the high altitude station. The calculations were based on the meteorological fields from the National Centers for Environmental Prediction (NCEP). The meteorological fields had a spatial resolution of $1^{\circ} \times 1^{\circ}$ and a temporal resolution of $3 \mathrm{~h}$.

Two altitude ranges were set as starting positions for the HYSPLIT back trajectories according to the separation of the air masses into BL and LFT. One starting point was set to the given altitude of the research station ( $4765 \mathrm{~m}$ a.s.l.) which lies above the altitude of the model mixing layer. Hence, the back trajectories starting from the top of the mountain represent the air mass transport in the lower free troposphere. The second starting point is variable and was set to half the model mixing layer depth above the model surface altitude at the given date and time. This assures that the second starting point lies within the boundary layer. The back trajectories starting from the second lower position account for air masses originating from the planetary boundary layer. The air masses reach the station due to nearby shallow convection or small-scale orographic lifting. None of these regional effects are represented by the global meteorological fields which served as input data.

The trajectories were calculated backwards for $240 \mathrm{~h}$ starting in $3 \mathrm{~h}$ intervals. They contain information on 
meteorological parameters along the transport pathway like relative humidity or surface precipitation. We included satellite observations into the trajectory analysis to extend the information of the air mass history by biomass burning - one of the main aerosol sources in the tropics (Bond et al., 2013).

We used the Global Monthly Fire Location Product (MCD14ML, Giglio et al., 2003, 2006; Giglio, 2010) and Burned Area Product (MCD45A1, Roy et al., 2005, 2008) which are retrieved from the Moderate Resolution Imaging Spectroradiometer (MODIS) observations on the Terra and Aqua satellites. The Global Monthly Fire Location Product was used in combination with the computed back trajectories to retrieve the respective information on air mass history. Precipitation data given by the HYSPLIT model was used to reduce possible impact of precipitation on the particle load along the transport pathway. It is based on the NCEP data. Fires along the transport pathway were only considered if no precipitation occurred between the fire event and the observation at the measurement site and if the trajectory was located within the boundary layer when passing over a biomass burning area. The Global Monthly Fire Location Product was extrapolated to a $0.1^{\circ} \times 0.1^{\circ}$ grid for the combination with the trajectories. In addition, fires that were detected up to three days prior to the trajectory overpass were considered. The result is the number of fire events since the last precipitation event (Sect. 4). Fire pixels were considered if their estimated detection confidence was nominal or high, that is, greater then $30 \%$ (see Giglio, 2010).

The MODIS Burned Area Product was used to estimate the burned area per month in the Venezuelan savannah for the period between 2000-2013. We considered a region between $6-11^{\circ} \mathrm{N}$ and $62-72.5^{\circ} \mathrm{W}\left(\sim 640 \times 10^{3} \mathrm{~km}^{2}\right)$ which covers most of the savannah upwind the observation site. The fire pixels have a horizontal resolution of $500 \mathrm{~m}$. Multiple counts of the same fire pixel per month were omitted. We use the burned area to discuss the three observed biomass burning seasons within a wider climatological context (Sect. 5.2).

Observations from the Cloud-Aerosol Lidar and Infrared Pathfinder Satellite Observation (CALIPSO) satellite (Winker et al., 2009) were used to investigate the average expansion of lifted aerosol layers downwind from the observation site. We used the Lidar Level $25 \mathrm{~km}$ Aerosol Layer Product. The top layer altitude and the surface elevation from GTOPO30 digital elevation map (DEM), both provided by the Aerosol Layer Product, were used to calculate the altitude above the surface of the upper most aerosol layer. In addition, we applied the Feature Classification Flags (Mielonen et al., 2009; Omar et al., 2009) to estimate the most frequent aerosol type of the upper most aerosol layer at the respective location. Data for the months February-April, that is, the months of the main biomass burning period in Venezuela (Morales et al., 1990), were averaged over the years of the in situ observations 2007-2009 (Sect. 5.1).

\section{Results of in situ observations}

\subsection{Meteorological conditions}

The meteorological conditions at the Pico Espejo and their seasonal variations are controlled by the north-south shift of the Intertropical Convergence Zone (ITCZ). It is characterised by deep convection and subsequent strong precipitation events. The ITCZ is located south of the Pico Espejo during northern hemispheric winter. Decreased convective activity and enhanced subsidence of air masses lead to rather dry conditions within the lower troposphere. The trade winds transport air masses from ENE to Venezuela. The influence of the ITCZ gets more prominent during the northern hemispheric summer when it migrates towards the north. It forces deep convection and precipitation in the region and leads to a change of the air mass origin as trade winds from ESE dominate the air mass transport. The effect of the migrating ITCZ and the subsequent change in ambient humidity can be clearly seen in the seasonal variation of the relative humidity RH in the LFT (Figs. 2 and 3). Typical for tropical regions, the seasonal cycle of the meteorological conditions at Pico Espejo can be divided into a dry and wet season. The dry season peaks from January till March and the wet season reaches its maximum between July and September.

The orography causes a pronounced diurnal cycle besides the seasonal cycle. Due to the high altitude of the research station measurements are mostly performed within the lower free troposphere during the night. However, during daytime surface heating and subsequent convection lead to an orographically driven upslope flow as air masses originating from the planetary boundary layer are lifted upwards and reach the station (Fig. 4).

\subsection{Seasonal cycle}

Table 1 summarises the mean values of each season observed within the LFT and the BL.

The relative humidity (RH) shows a high variability in the LFT for both, dry and wet season with a standard deviation between 25-27\% (see also time series in Fig. 2). However, RH increases from $45 \%$ to $67 \%$ from the dry to the wet season. The temperature remains constant at $t \sim 0{ }^{\circ} \mathrm{C}$. The average particle number and volume concentrations within the LFT during the wet season can be considered as mean background values which are rather stable throughout the year. The particle volume $V$ reaches an average of $0.19 \mu \mathrm{m}^{3} \mathrm{~cm}^{-3}$ and the average absorption coefficient $b_{\text {abs }}$ is $0.15 \mathrm{Mm}^{-1}$.

The relative humidity and ambient temperature remain constant throughout the seasons for BL air masses $\left(\mathrm{RH}=82-86 \%, t \sim 2{ }^{\circ} \mathrm{C}\right)$. The meteorological seasonal cycle has a large impact on all observed aerosol parameters within the BL. The particle volume $V$ reaches an average of $0.49 \mu \mathrm{m}^{3} \mathrm{~cm}^{-3}$ in the wet and $1.4 \mu \mathrm{m}^{3} \mathrm{~cm}^{-3}$ during the dry season. The absorption coefficient $b_{\mathrm{abs}}$ increases from 
Table 1. Arithmetic mean and standard deviation of observed parameters at Pico Espejo for different seasons and air masses; relative humidity $\mathrm{RH}(\%)$, temperature $t\left({ }^{\circ} \mathrm{C}\right)$, number of fire events since the last precipitation event according to the trajectory analysis (\#), ambient particle volume concentration $V\left(D_{\mathrm{p}}=10-470 \mathrm{~nm}\right)\left(\mu \mathrm{m}^{3} \mathrm{~cm}^{-3}\right)$, ambient aerosol number concentration $\left.N^{(} \mathrm{cm}^{-3}\right)$, refractory particle number concentration $N_{300}{ }^{\circ} \mathrm{C}\left(\mathrm{cm}^{-3}\right)$, ratio of refractory and ambient particle number concentration $N_{300}{ }^{\circ} \mathrm{C} / N(0-1)$, and absorption coefficient $b_{\mathrm{abs}}\left(\mathrm{Mm}^{-1}\right)$. To convert the ambient concentrations and $b_{\mathrm{abs}}$ to standard temperature and pressure please use stp $=1.77( \pm 0.01) \mathrm{amb}$.

\begin{tabular}{|c|c|c|c|c|c|c|c|c|}
\hline Season & $\begin{array}{l}\mathrm{RH} \\
(\%)\end{array}$ & $\begin{array}{c}t \\
\left({ }^{\circ} \mathrm{C}\right)\end{array}$ & $\begin{array}{l}\text { Fire events } \\
\qquad(\#)\end{array}$ & $\left(\mu \mathrm{m}^{3} \mathrm{~cm}^{-3}\right)$ & $\begin{array}{c}N \\
\left(\mathrm{~cm}^{-3}\right)\end{array}$ & $\begin{array}{l}N_{300^{\circ} \mathrm{C}} \\
\left(\mathrm{cm}^{-3}\right)\end{array}$ & $\begin{array}{c}N_{300{ }^{\circ} \mathrm{C}} / \mathrm{N} \\
(0-1)\end{array}$ & $\begin{array}{c}b_{\mathrm{abs}} \\
\left(\mathrm{Mm}^{-1}\right)\end{array}$ \\
\hline \multicolumn{9}{|c|}{ Boundary layer } \\
\hline dry & $82 \pm 8.7$ & $1.8 \pm 1.9$ & $4.8 \pm 11$ & $1.4 \pm 1.3$ & $730 \pm 470$ & $510 \pm 420$ & $0.64 \pm 0.19$ & $0.91 \pm 1.2$ \\
\hline wet & $86 \pm 7.9$ & $1.7 \pm 2.1$ & $0.6 \pm 2.4$ & $0.49 \pm 0.41$ & $480 \pm 260$ & $230 \pm 130$ & $0.46 \pm 0.14$ & $0.32 \pm 0.38$ \\
\hline \multicolumn{9}{|c|}{ Lower free troposphere } \\
\hline dry & $45 \pm 27$ & $0.76 \pm 2.2$ & $0.1 \pm 0.9$ & $0.47 \pm 0.70$ & $480 \pm 310$ & $260 \pm 290$ & $0.50 \pm 0.20$ & $0.36 \pm 0.59$ \\
\hline wet & $67 \pm 25$ & $-0.02 \pm 1.9$ & $0.0 \pm 0.3$ & $0.19 \pm 0.25$ & $390 \pm 270$ & $150 \pm 94$ & $0.39 \pm 0.16$ & $0.15 \pm 0.26$ \\
\hline
\end{tabular}

$0.32 \mathrm{Mm}^{-1}$ to $0.91 \mathrm{Mm}^{-1}$ (factor 2.8 ) from the wet to the dry season. However, both parameter show a standard deviation of $\sim 100 \%$. Recent studies showed an increase of $b_{\text {abs }}$ from the wet to the dry season from $0.5 \mathrm{Mm}^{-1}$ to $2.8 \mathrm{Mm}^{-1}$ (factor 5.6) in the Amazon rain forest at $110 \mathrm{~m}$ a.s.l. (Rizzo et al., 2013). This is twice the increase of $b_{\text {abs }}$ compared to our observations of biomass burning in the savannah. The trajectory analysis shows the highest average number of fire events since the last precipitation event of 3 for the dry BL. This is consistent with the increased particle load during the biomass burning season.

\subsection{Interannual variability}

Figures 2 and 3 show the respective time series of relative humidity (RH), ambient particle volume concentration for particles smaller $470 \mathrm{~nm}(V)$, refractory particle number concentration $\left(N_{300}{ }^{\circ} \mathrm{C}\right)$, and the absorption coefficient $\left(b_{\text {abs }}\right)$ for the LFT and BL. Each time series shows the single data (15 min average) and the adjacent average over one month as well as its standard deviation.

In the LFT the average RH increases from the dry to the wet season from 30-80\%. However, it features a high daily variability throughout the observation period. The wet seasons of 2007 and 2008 show no significant difference in the maximum relative humidity. However, the dry season of $2008\left(\mathrm{RH}_{\min } \sim 30 \%\right)$ features drier air masses on average than the dry season of $2009\left(\mathrm{RH}_{\min } \sim 40 \%\right)$. Both dry seasons also show different months of lowest RH with the beginning of February in 2008 and the end of December 2008 for the dry season of 2009. The minimum RH in 2007 cannot be assigned. RH was $45 \%$ at the beginning of the observations in March 2007. The RH in the BL features a relatively small interannual variability. Its average lies between 80-90\%.

The enhancement of particulate matter during the dry season within the BL is also reflected in the LFT. The air masses mix due to (dry) convection and orographic lift- ing which is induced by the mountain range. Thus, primary particles such as soot are mixed into the LFT. However, the total concentration is diluted by the rather clean and dry free tropospheric air. The particle volume concentrations in the $\mathrm{BL}$ (Fig. 3) reach their respective maxima in mid-March 2007, end of March 2008 and midApril 2009. The dry season maxima decrease continuously from 2007 to $2009\left(2.9 / 2.6 / 2.1 \mu^{3} \mathrm{~cm}^{-3}\right)$. A similar trend can be observed for the ambient particle number concentrations $N\left(1500 / 1200 / 750 \mathrm{~cm}^{-3}\right)$ and the refractory particle number concentrations $N_{300}{ }^{\circ} \mathrm{C}\left(1300 / 720 / 470 \mathrm{~cm}^{-3}\right)$. $b_{\mathrm{abs}}$ also shows its maximum in the dry season of 2007 $\left(3.8 \mathrm{Mm}^{-1}\right)$. However, $b_{\mathrm{abs}}$ features an increase from 2008 to 2009 from $2.0 \mathrm{Mm}^{-1}$ to $2.6 \mathrm{Mm}^{-1}$, that is, an overall decrease of biomass burning aerosol was observed from 20072009.

The interannual variability will be further discussed using satellite observations in Sect. 5.2.

\subsection{Diurnal cycle}

The mixing of the two air masses, BL and LFT, can be observed by examining the diurnal cycles in Fig. 4. The whole dataset combing BL and LFT data was used for the calculation of the diurnal cycles. However, the data were split into wet (blue) and dry (red) season. The relative humidity shows a clear diurnal cycle particularly during the dry season. During the night, which may be considered as free tropospheric air, the minimum of the hourly average drops to $\mathrm{RH}=55 \%$ at 06:00 LT (local time). The average relative humidity increases during daytime to a maximum of $\mathrm{RH}=81 \%$ at 16:00 LT when boundary layer air masses are lifted to the station.

During the dry season the ambient particle number concentration reaches its plateau of maximum concentrations between 12:00-17:00 LT. The ambient particle volume concentration and the refractory particle number concentration 

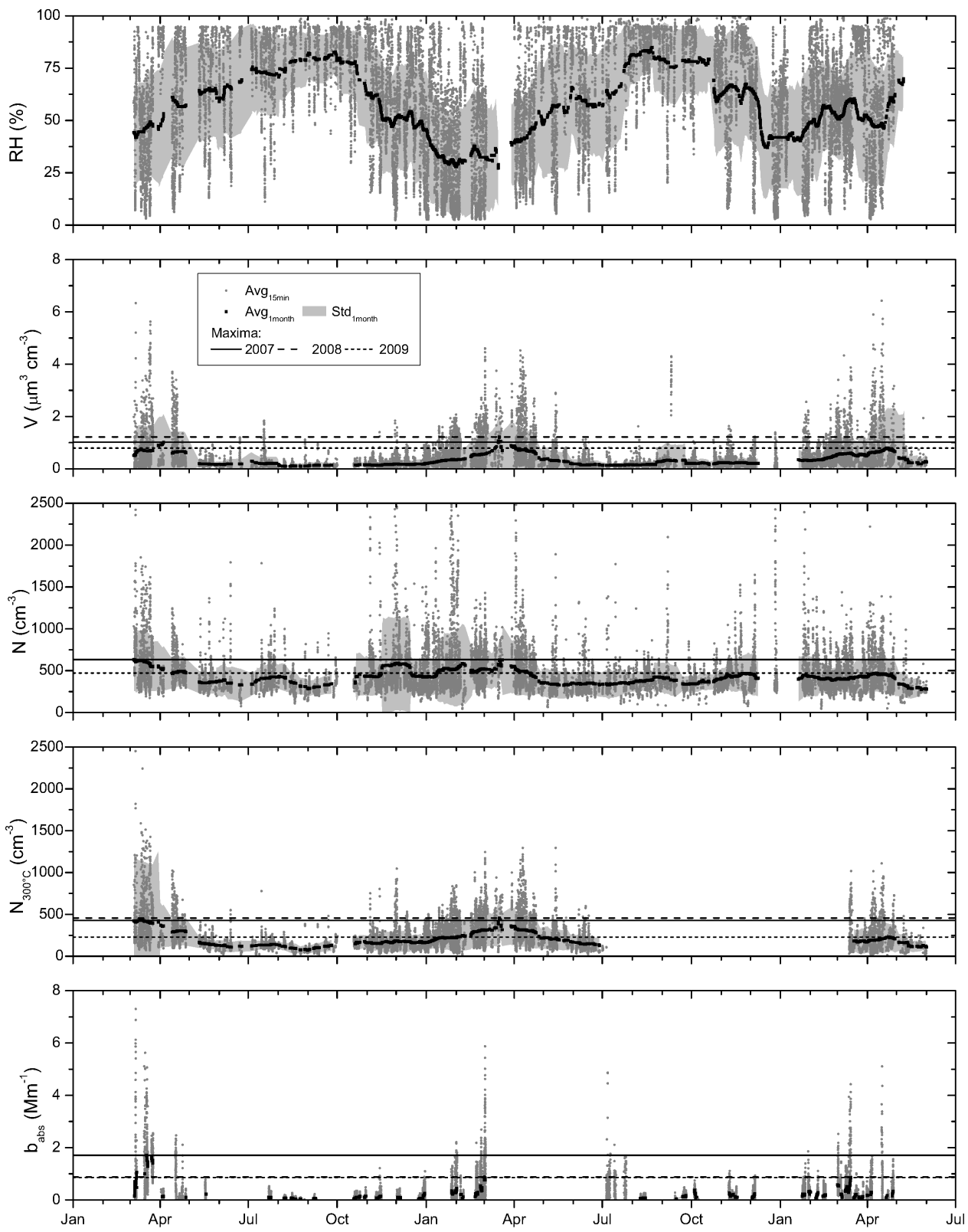

Fig. 2. Time series of data observed in the LFT comprising relative humidity RH $(\%)$, ambient particle volume concentration $V\left(D_{\mathrm{p}}=10-\right.$ $470 \mathrm{~nm})\left(\mu \mathrm{m}^{3} \mathrm{~cm}^{-3}\right)$, ambient aerosol number concentration $N\left(\mathrm{~cm}^{-3}\right)$, refractory particle number concentration $N_{300}{ }^{\circ} \mathrm{C}\left(\mathrm{cm}^{-3}\right)$, and absorption coefficient $b_{\text {abs }}\left(\mathrm{Mm}^{-1}\right)$. The small dots in dark grey indicate 15 min averages, the black squares the one monthly adjacent average and its standard deviation in light grey. Horizontal lines show the maxima of the one monthly adjacent average for each dry season.

continuously increase until they reach their maxima between 14:00-16:00 LT. The early increase in ambient particle number requires additional sources next to the advection of existing particulate matter. The results of Schmeissner et al. (2011) indicate the possible presence of new particle formation. New particle formation was also observed during prior studies at high altitude observation sites and aircraft studies within different climatic regions (e.g. Weingartner et al., 1999; Venzac et al., 2008; Kivekäs et al., 2009; Hallar et al., 2011b). However, a detailed analysis of new particle formation observed at the Pico Espejo would be beyond the scope of this paper and has to be accomplished in further work.

The rather high mean values of $b_{\mathrm{abs}}$ in the early afternoon hours compared to its median values result from single events. $b_{\text {abs }}$ reaches up to $8-10 \mathrm{Mm}^{-1}$ during those episodes of high absorption. 

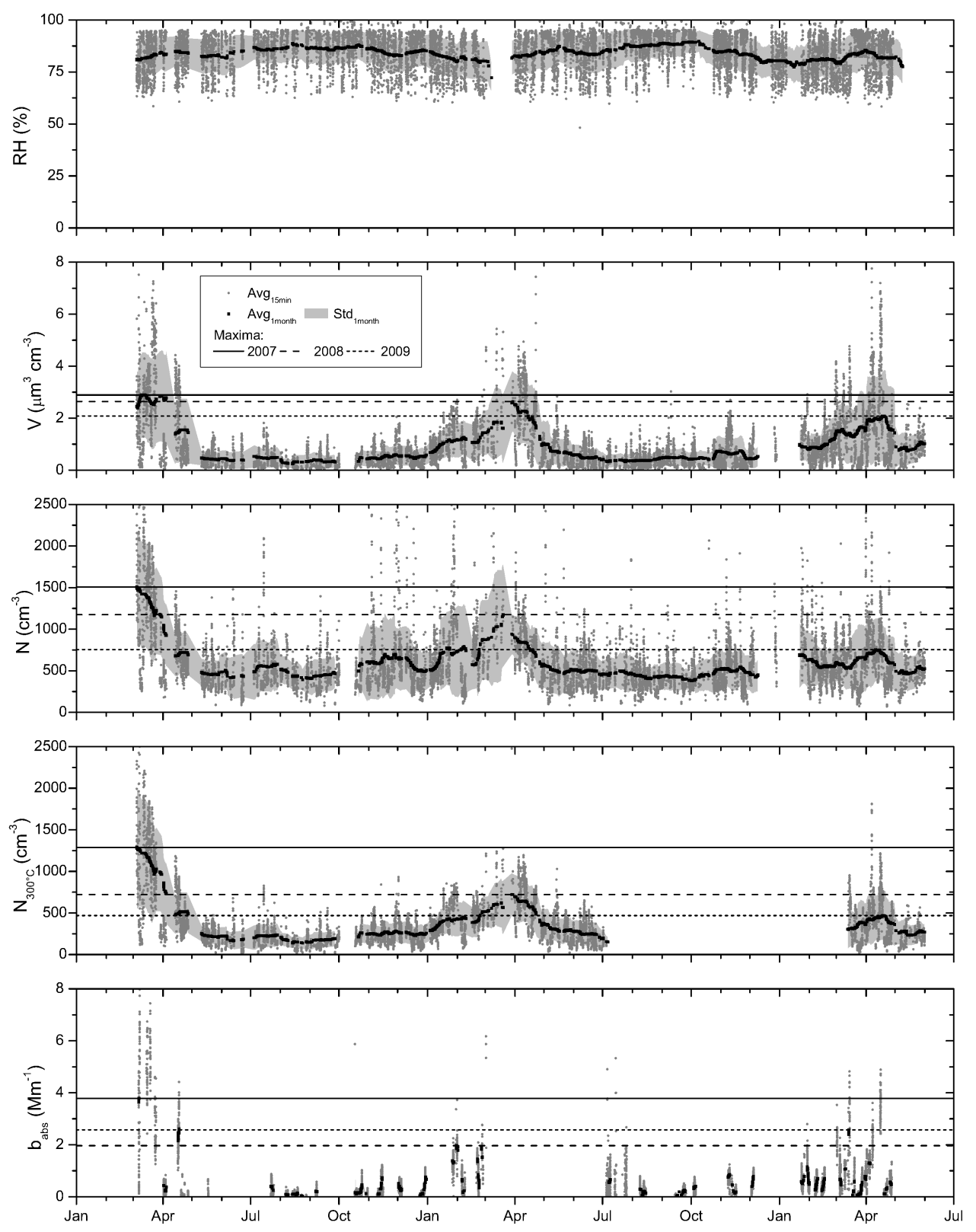

Fig. 3. Same as Fig. 2 but for data observed in the BL.

In general, minimum aerosol concentrations could be observed during the night-time till the early morning hours. The mixing of boundary layer air into free tropospheric air begins between 09:00-10:00 LT. Interestingly, the observed aerosol concentrations reach their maxima during the wet season between 16:00-17:00 LT and during the dry season between 14:00-16:00 LT. However, due to the location close to the equator there is only little time shift in sunrise (less than one hour) within the year with earlier sunrise during the wet season. This would even trigger rather earlier than late convection during the wet season. Increased cloud cover and latent heat production delays the rise of the boundary layer. Al- though the sunshine intensity is slightly stronger during the wet season a considerable amount of solar radiation is scattered by clouds or required to evaporate water in the morning hours from the moist surface during the wet season. This energy is already available during the morning hours in the dry season to produce sensible heat on the dry surface and to drive convection on the mountain slope. Thus, the boundary layer reaches the mountain station about two hours earlier during the dry season than during the wet season. 

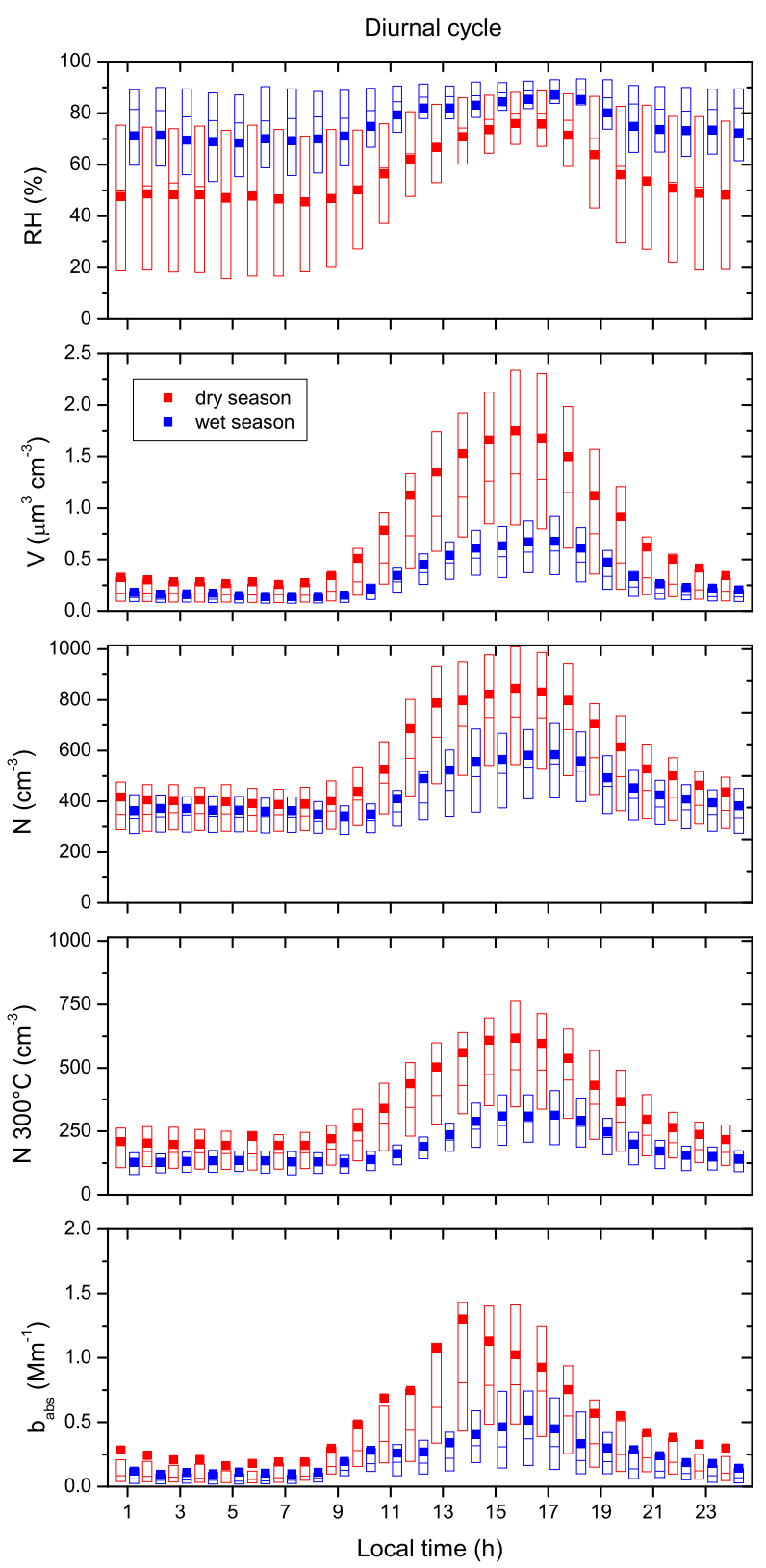

Fig. 4. Diurnal cycles of relative humidity RH (\%), ambient particle volume concentration $V\left(D_{\mathrm{p}}=10-470 \mathrm{~nm}\right)\left(\mu \mathrm{m}^{3} \mathrm{~cm}^{-3}\right)$, ambient aerosol number concentration $N\left(\mathrm{~cm}^{-3}\right)$, refractory particle number concentration $N_{300}{ }^{\circ} \mathrm{C}\left(\mathrm{cm}^{-3}\right)$, and absorption coefficient $b_{\text {abs }}\left(\mathrm{Mm}^{-1}\right)$. The bars indicate 25 th percentile-median-75th percentile, the squares represent the arithmetic mean. Red colour indicates observations during the dry season, blue colour during the wet season. The time is local time (UTC-4.5 h).

\section{Identification of source regions}

One possible source region of South American biomass burning plumes reaching the research station are the savannah regions of Venezuela (Sanhueza et al., 1987), as explained before. Further, the Amazon region may serve as a possible source region of biomass burning aerosol. Approximately $40 \%$ of the total particulate mass which is released by deforestation activities in the Tropics originates from biomass burning in the Amazon region (Longo et al., 2009). In addition, long-range transport of biomass burning aerosol and dust from northern and tropical Africa to South America via the Atlantic was observed by foregoing studies (Edwards et al., 2006; Ansmann et al., 2009; Adams et al., 2012; Rizzo et al., 2013).

We used HYSPLIT trajectories in combination with the MODIS Global Monthly Fire Location Product to detect possible source regions during the dry and wet season. Figure 5a and $\mathrm{b}$ show fire events within the last 10 days that possibly effected the air masses reaching the Pico Espejo. The analysis is divided into two subsets; one not considering the precipitation during the air mass transport (Fig. 5a) and one considering precipitation between the source and the observation site (Fig. 5b). In both cases the main source region is the Venezuelan savannah during the dry season. A nonnegligible amount of fire events are located in the Amazon basin. However, with the observation site located north of the equator and the Amazon basin in the Southern Hemisphere, the biomass burning season in the Amazon basin coincides with the wet season in Venezuela. Hence, particulate matter from Amazonian biomass burning is very likely to be scavenged by precipitation during the transport towards Venezuela.

Long-range transport from West Africa seems possible when considering the trajectory analysis. Additional analysis not shown here using the FLEXPART dispersion model (Stohl et al., 2005) indicates possible impact from African biomass burning, too. However, no signal in the particle properties could be significantly connected to those events. The particle observations are dominated by the regional biomass burning. Thus, the signal of long-range transport may be masked by regional biomass burning during the dry season. During the rainy season most particulate matter is removed by wet scavenging. Long-lived trace gases like $\mathrm{CO}$ are left in the atmosphere as possible tracers of biomass burning but were not observed at the station.

We compared relative humidity, the particle volume concentration, the number concentration of ambient and refractory particles, and the absorption coefficient to the number of fire events along the transport pathway since the last precipitation event (Fig. 6). The concentrations are binned into intervals of 5 fire events, each. Averages were calculated for each bin if the number of observations (each observation being a $15 \mathrm{~min}$ average) exceeded 20. Most back trajectories which could be associated with biomass burning events started within the model boundary layer. The relative humidity indicates this feature with a constant relative humidity greater than $80 \%$ for 5 and more biomass burning events. Less biomass burning events (0-5) indicate drier air masses which can be partly associated with the free troposphere. 


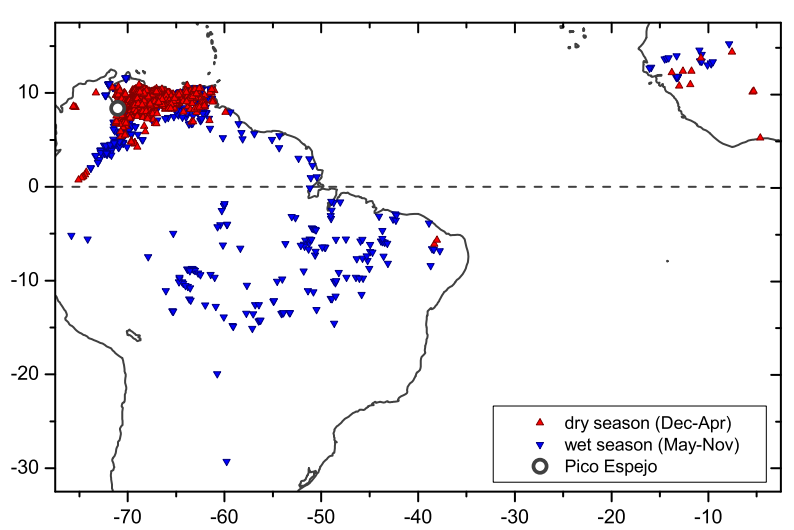

(a)

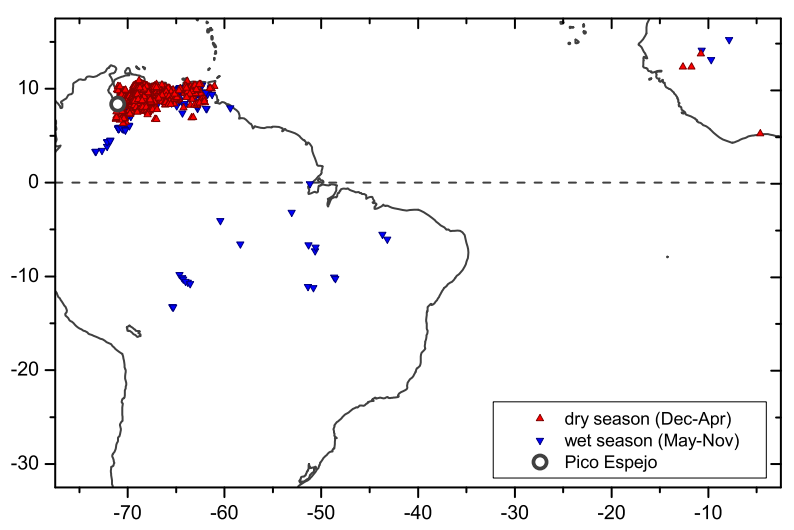

(b)

Fig. 5. Possible fire events affecting the observations according to the trajectory analysis ( -10 days). Red triangles represent the Venezuelan dry season, blue triangles its wet season. Panel (a) shows all possible fire events not accounting for precipitation along the air mass transport path way. Panel (b) shows all fire events excluding events with precipitation along the transport path way.

The aerosol volume concentration $V$ shows an increase from $0.5 \mu \mathrm{m}^{3} \mathrm{~cm}^{-3}$ at $0-5$ fire events to $2.7 \mu \mathrm{m}^{3} \mathrm{~cm}^{-3}$ at $55-60$ fire events. The average number concentration of refractory particles $N_{300}{ }^{\circ} \mathrm{C}$ increases from $270 \mathrm{~cm}^{-3}$ at $0-5$ fire events to a maximum of $1200 \mathrm{~cm}^{-3}$ at $50-55$ fire events. Only few bins of fire events could be connected to $b_{\text {abs }}$ measurements. However, an increase of the average $b_{\mathrm{abs}}$ with increasing number of fire events can be observed, too, from $0.4 \mathrm{Mm}^{-1}$ at $0-5$ fire events to a maximum of $1.8 \mathrm{Mm}^{-1}$ at $10-15$ fire events.

The average ambient particle number concentration increases from $500 \mathrm{~cm}^{-3}$ at $0-5$ fire events to $1700 \mathrm{~cm}^{-3}$ at $45-$ 50 fire events. The increase in number can most frequently be associated with new particle formation, which must not necessarily be linked to biomass burning. However, the tra-
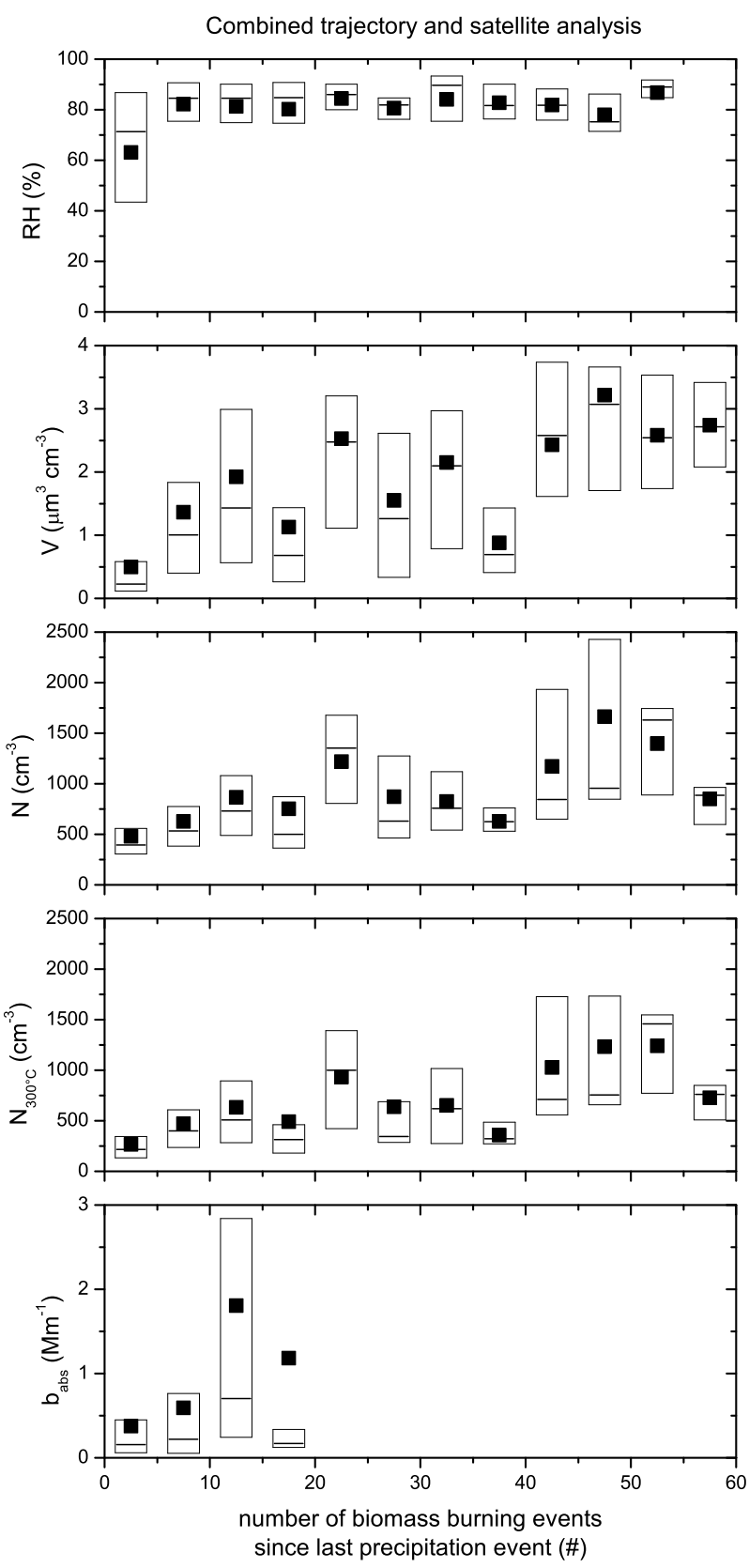

Fig. 6. Relative humidity RH (\%), ambient particle volume concentration $V\left(D_{\mathrm{p}}=10-470 \mathrm{~nm}\right)\left(\mu \mathrm{m}^{3} \mathrm{~cm}^{-3}\right)$, ambient aerosol number concentration $N\left(\mathrm{~cm}^{-3}\right)$, refractory particle number concentration $N_{300}{ }^{\circ} \mathrm{C}\left(\mathrm{cm}^{-3}\right)$, and absorption coefficient $b_{\mathrm{abs}}\left(\mathrm{Mm}^{-1}\right)$ versus the number of fire events detected since the last precipitation event according to the trajectory analysis ( -10 days).

jectory analysis indicates that biomass burning contributes to a significant amount to the increase in number concentration. Secondary biomass burning products such as sulfate or organic species are released by fires next to primary particles (Reid et al., 2005; Pratt et al., 2011) and might contribute to 
an increase in particle number concentration and certainly in particle volume concentration.

The high variability of the trajectory analysis, which is caused by the uncertainty of the trajectories amongst others, does not allow for a significant correlation throughout the whole number spectrum of fire events. Nevertheless, the trajectory analysis shows that biomass burning from the nearby Venezuelan savannah region is the main source of absorbing primary particulate matter at the Pico Espejo.

\section{Analysis of satellite observations}

In the following section we will identify the regions that are possibly affected by the uplifted biomass burning plumes using CALIPSO satellite observations. In addition we examine the biomass burning intensity in the wider region of Venezuela of the last $12 \mathrm{yr}$ (end of 2000 until beginning of 2013) with the help of MODIS satellite products to put the presented in situ observations into a climatological context.

\subsection{Transport of smoke plumes downwind from the source region}

The soot particles emitted by the biomass burning fires can directly affect the radiative transfer above a region by absorbing light and heating the ambient air which possibly leads to a reduction of the cloud cover or can change regional cloud properties by providing additional cloud condensation nuclei (Ten Hoeve et al., 2012). Plumes containing soot particles also change the local atmospheric stability due to the ability to heat the ambient air by absorbing the solar radiation. Hence, elevated biomass burning layers have the potential of additional lifting, increasing persistence and thus longer lifetimes in the free troposphere (Boers et al., 2010). At the top of the atmosphere semi-direct radiative effects can differ in sign depending on the location of the biomass burning plumes and their underlying surface, that is, if they are located above land (positive semi direct radiative effect) or ocean (negative semi direct radiative effect) (Sakaeda et al., 2011).

We use the CALIPSO Level $25 \mathrm{~km}$ Aerosol Layer product to estimate the region which can be affected by biomass burning plumes downwind Venezuela. The satellite data was averaged for the months from February to April and the years 2007 to 2009. Figure 7a shows the altitude above the surface of the upper most aerosol layer. Maximum altitudes reaching more than $7 \mathrm{~km}$ can be observed above the Amazon region where the ITCZ is located at that time. The altitude is generally lower in the northern hemispheric South America during the dry season. The altitude above surface increases from the Venezuelan savannah plains towards the mountain range of the Andes from 2-3 km to 4-5 km. Downwind, that is, WSW of the Andes, the uplifted aerosol layers maintain an altitude between $3-5 \mathrm{~km}$ above the surface of the Pacific ocean. Along with the trade winds the transport of the elevated aerosol layers can be observed with the satellite data for more than $1500 \mathrm{~km}$. The aerosol layers almost reach the Galápagos Islands.

The transport pathway is supported by 10 day forward trajectory calculations which are indicated by dashed lines in Fig. 7a and $\mathrm{b}$. The trajectories were started from the top of the model boundary layer at the location of the Pico Espejo to simulate the possible transport of the residual layers. The dashed lines represent the average area that can be reached between February and May by the biomass burning layers according to the trajectory calculations. The area extends dominantly towards the WSW of the Pico Espejo as expected by the prevailing wind conditions.

The Aerosol Feature Classification product shows that the elevated aerosol layer downwind from the northern hemispheric part of South America are mostly classified as "smoke" (Fig. 7b). Those "smoke" layers originate from biomass burning fires and contain to a great extend light absorbing soot.

\subsection{2 years of satellite observations - the in situ measurements in a climatological context}

The interannual variability discussed in Sect. 3.3 shows a decrease in concentrations of primary absorbing aerosol particles from the dry season in 2007 to the dry season in 2009. This decrease in aerosol concentrations indicates a decrease in biomass burning activity in the main source region of the Venezuelan savannah plains. Figure 8 shows the burned area per month for the years 2000 to 2013. The area of interest spans a rectangle of $\sim 640 \times 10^{3} \mathrm{~km}^{2}$ which comprises the region of the Venezuelan savannah. The maximum burned area per month decreases from the dry season 2007 to the dry season 2009 from $9300 \mathrm{~km}^{2}$ to $720 \mathrm{~km}^{2}$. This decline of biomass burning area is consistent with the observed particle concentrations and explains most of the decrease.

Several reasons can lead to a change in biomass burning activity - the most prominent being the prevailing meteorological conditions. But also legal regulations due to environmental pressures and weakening demand for new agricultural land are causes to reduce regional biomass burning (Streets et al., 2004). For example, Koren et al. (2007) found a reversal trend from formerly increasing biomass burning intensity in the Amazon Basin to a sharp decrease in 2006. They speculated that the decrease might result from a trinational policy shift which was implemented in 2006 in the Amazon area (Brown et al., 2006). However, Koren et al. (2007) mention that this abrupt decrease of fires may have also been the effect of a positive precipitation anomaly in the rainy season of the same year. Further, Torres et al. (2010) reported a huge increase of biomass burning activity in 2007 followed by a decline of fires in 2008 and 2009. Although the study comprises whole South America with a focus on the Amazon Basin the results match with our observations. 

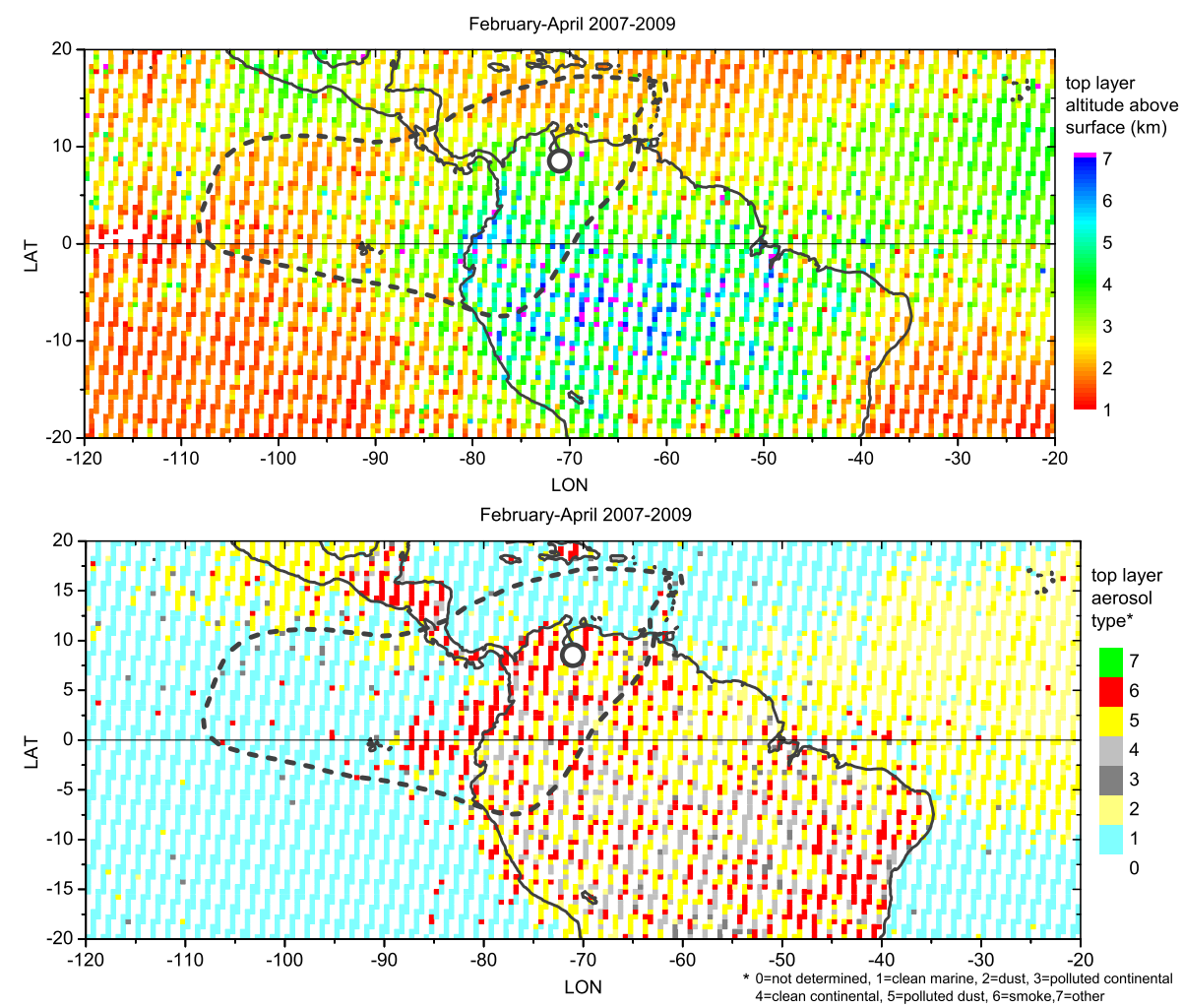

Fig. 7. CALIPSO satellite observations averaged for February-April for the years 2007-2009. Panel (a) shows the altitude above the surface of the upper most aerosol layer and panel (b) its dominating aerosol type (see Sect. 2.4 for details). Both parameters are retrieved from the LIDAR Level $25 \mathrm{~km}$ aerosol layer product. The dashed line indicates the average area which is covered by 10 day forward trajectories within the same period.

Torres et al. (2010) suggest, that the strong decline in 2008 might be influenced by non-meteorological factors.

Since 2008, the Venezuelan State changed legal regulations related to forest fires (Ley de Bosques y Gestión Forestal, 2008). Modifications on the legal definition of fire protected areas as well as the creation of several types of firefighter leagues, including the forest ranger brigade and the communal brigades, could explain the decline of biomass burning. However, the regulations may only have an impact from the 2009 biomass burning season on. So far, the time series of the burned area per month does not show a continuous trend within the years 2000 to 2013. Thus, the analysis does not show an indication for a successful implementation of the legal regulations, yet.

Seasonal and inter-annual variations in the meteorological conditions can also affect the degree of biomass burning - next to legal regulations to control forest fires. One major meteorological driver for the intensities of biomass burning seasons in the tropics is the El Niño-Southern Oscillation (ENSO). Increases in fire emissions seem to be linked with El Niño induced drought and could be observed in central and northern South America (van der Werf et al., 2004). The ENSO episodes vary between a warm and dry episode (El Niño) and a cold and wet episode (La Niña) in tropical
South America. El Niño and La Niña typically recur every 2 to $7 \mathrm{yr}$ (McPhaden et al., 2006). Rainfall amounts higher than normal occur west of the Andes and lower precipitation can be observed in the Amazon Basin (Hoffmann, 2003). Largest changes in the frequency of extreme precipitation events occur in the rainy season preceding the following dry biomass burning season. Reduced frequency of heavy rainfall appears during El Niño episodes in north-western South America in August and vice versa during La Niña (Giannini et al., 2000; Grimm and Tedeschi, 2009).

We added information on sea surface temperature (SST) anomalies in the Pacific region to the time series in Fig. 8 to indicate warm and dry episodes (El Niño) and cold and wet episodes (La Niña). The data was retrieved from the National Oceanic and Atmospheric Administration (NOAA) National Weather Service Climate Prediction Center. Positive SST anomalies greater than $0.5^{\circ} \mathrm{C}$ (red) are associated with El Niño. Negative SST anomalies smaller than $-0.5^{\circ} \mathrm{C}$ (blue) are associated with La Niña. Figure 8 shows, that the intense biomass burning seasons in 2003, 2007, and 2010 followed preceding El Niño conditions. A continuous decrease in burned area appeared in the years 2008-2009 and 20112012. Both can be associated with La Niña conditions in the same years. Interestingly, a decrease in burned area can be 


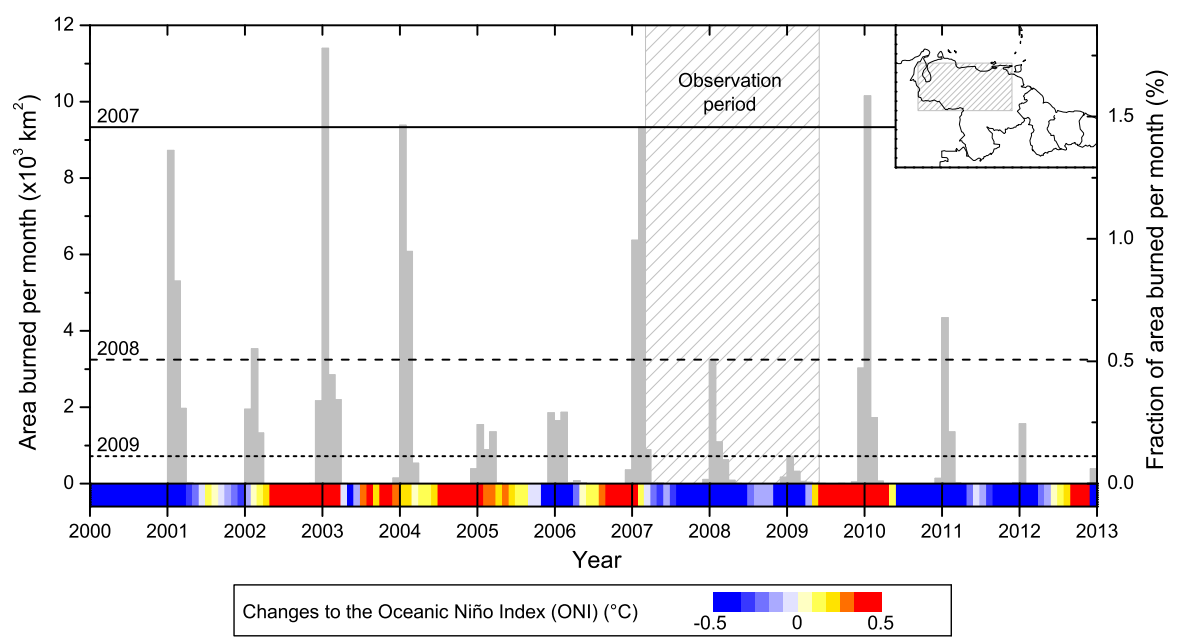

Fig. 8. Time series of the area affected by fires for the wider region of Venezuela $\left(\mathrm{km}^{2}\right)$ (see Sect. 2.4 for details). The data is based on MODIS satellite observations. The horizontal lines indicate the maxima for the dry seasons during the observation period at the Pico Espejo. The colour coded $x$ axes shows periods with El Ninõ conditions (red) and La Niña conditions (blue).

seen for consecutive warm and dry El Niño episodes. After the intense biomass burning season in 2003, the burned area decreases from 2004 to 2005 - all three years featured El Niño conditions. This indicates that a lack of burning fuel and less demand on agricultural biomass burning can also result in less burned area. On the other hand, all intense biomass burning seasons feature El Niño conditions, which follow years of cold and wet La Niña conditions (e.g. 2007 and 2010), that is, less biomass burning but more intense regrowth of grass and scrubs was possible before the warm and dry El Niño period began. This means that more burning fuel was available in a biomass burning season during a warm and dry El Niño episode, if it followed a cold and wet La Niña episode.

The overall trend of the years 2000 to 2012 and especially the link between the intense biomass burning season in 2007 with El Niño and the weak biomass burning seasons in 2008 and 2009 with La Niña indicate that the decrease of observed fire events and thus particle concentrations are dominated by ENSO related meteorological conditions and might mask local legal regulations.

\section{Summary and conclusion}

We presented the first long-term in situ observations of biomass burning aerosol in the tropical lower free troposphere (LFT). The special location of the observation site at the Pico Espejo at an altitude of $4765 \mathrm{~m}$ a.s.l. allows for observations of free tropospheric air masses as well as boundary layer (BL) air masses. BL air masses reach the station during daytime through orographic lifting and shallow convection. The Pico Espejo is located downwind from the Venezuelan savannah where frequent biomass burning occurs during the end of the dry season between December and April. The Venezuelan savannah was found to be the main source region of biomass burning aerosol during the dry season. Fires in the Amazon basin, one of the major sources of southern hemispheric biomass burning emissions (Streets et al., 2004; Edwards et al., 2006), coincide with the wet season of the Northern Hemisphere. Hence, wet scavenging of particles during the transport of air masses from the Amazon basin towards the northern part of South America significantly reduced the aerosol concentrations. No evidence of long-range transport of biomass burning emissions from Africa in the LFT or BL could be found in the observed particle properties. However, long-lived trace species like $\mathrm{CO}$ were not observed.

Particle concentrations in the LFT were found to be rather low and stable. During the wet season the ambient sub-micron particle volume $\mathrm{V}$ averaged at $0.19 \pm$ $0.25 \mu^{3} \mathrm{~cm}^{-3}$, refractory particle number concentrations at $N_{300}{ }^{\circ} \mathrm{C}$ at $150 \pm 94 \mathrm{~cm}^{-3}$ and the absorption coefficient $b_{\text {abs }}$ at $0.15 \pm 0.26 \mathrm{Mm}^{-1}$. Maximum particle concentrations were found during the dry biomass burning season in BL air masses. They reached $V=1.4 \pm 1.3 \mu \mathrm{m}^{3} \mathrm{~cm}^{-3}, N_{300}{ }^{\circ} \mathrm{C}=$ $510 \pm 420 \mathrm{~cm}^{-3}$ and $b_{\mathrm{abs}}=0.91 \pm 1.2 \mathrm{Mm}^{-1}$, respectively. The signal of the dry biomass burning season in the LFT is rather low compared to the $\mathrm{BL}$ although the seasonal variation of particle concentrations can be seen in the LFT. This indicates that on large scale the particle removal processes like wet scavenging in clouds work very effectively and limit the vertical transport of particles into the free troposphere.

CALIPSO satellite observations showed that layers of biomass burning aerosol were lifted on the upwind side of the northern end of the Andes. Those elevated "smoke" layers were transported downwind from the Andes westward 
towards the Pacific ocean at an altitude of approximately 3$5 \mathrm{~km}$. The biomass burning extended on average towards the Galápagos Islands and may perturb the solar radiation and atmospheric stability on a larger scale (Bellouin et al., 2005).

The observations at the Pico Espejo covered three dry seasons from 2007-2009. A distinct decrease of dry season particle concentrations was observed within this period. The analysis of fire activity in the wider region of Venezuela using MODIS satellite observations showed that the decrease of particle concentrations can be associated with a decrease in biomass burning activity. In all, $12 \mathrm{yr}$ of MODIS data indicated that the interannual variability in biomass burning activity in this region can be linked to varying meteorological conditions induced by the El Niño-Southern Oscillation (ENSO). Low biomass burning activity in the Venezuelan savannah tended to follow La Niña conditions, high biomass burning activity followed El Niño conditions. In addition, legal regulations concerning biomass burning were passed by the Venezuelan government in 2006 and 2008. So far, the results of the legal regulations might be masked by the meteorological conditions. However, on a long-term base the benefits of the legal regulations and their impacts on the regional climate might be visible. Thus, future continuous observations, both, in situ and remote sensing, are beneficial to examine the impact of legal regulations whilst considering interannual variations of the meteorological conditions.

Acknowledgements. We thank the members of the CALIPSO and MODIS projects for giving us access to data products through their web ordering systems. The CALIPSO data were obtained from the NASA Langley Atmospheric Sciece Data Center (ASDC) (http://www-calipso.larc.nasa.gov). The MODIS data were obtained through the online Data Pool at the NASA Land Processes Distributed Active Archive Center (LP DAAC), USGS/Earth Resources Observation and Science (EROS) Center, Sioux Falls, South Dakota (https://lpdaac.usgs.gov/get_data). Information on vegetation cover was retrieved from the NASA Global Land Data Assimilation System (GLDAS) (http://ldas.gsfc.nasa.gov/gldas). Changes to the Oceanic Niño Index (ONI) were provided by the National Oceanic and Atmospheric Administration (NOAA) National Weather Service Climate Prediction Center (http://www.cpc.ncep.noaa.gov/products/analysis_monitoring/ ensostuff/ensoyears.shtml). This work has been funded by the Swedish Research Council (VR, projects \# 2004-4135 (OFTA) and \# 2009-3007 (AVIAC)), the Swedish International Development Cooperation Agency (SIDA) and the Bolin Centre for Climate Research.

Edited by: V.-M. Kerminen

\section{References}

Ackerman, A. S., Toon, O. B., Stevens, D. E., Heymsfield, A. J., Ramanathan, V., and Welton, E. J.: Reduction of Tropical Cloudiness by Soot, Science, 288, 1042-1047, doi:10.1126/science.288.5468.1042, 2000.

Adams, A. M., Prospero, J. M., and Zhang, C.: CALIPSO Derived Three-Dimensional Structure of Aerosol over the Atlantic and Adjacent Continents, J. Climate, 25, 6862-6879, doi:10.1175/JCLI-D-11-00672.1, 2012.

Andreae, M. O. and Gelencsér, A.: Black carbon or brown carbon? The nature of light-absorbing carbonaceous aerosols, Atmos. Chem. Phys., 6, 3131-3148, doi:10.5194/acp-6-3131-2006, 2006.

Andreae, M. O., Artaxo, P., Fischer, H., Freitas, S. R., Grégoire, J.-M., Hansel, A., Hoor, P., Kormann, R., Krejci, R., Lange, L., Lelieveld, J., Lindinger, W., Longo, K., Peters, W., de Reus, M., Scheeren, B., Silva Dias, M. A. F., Ström, J., van Velthoven, P. F. J., and Williams, J.: Transport of biomass burning smoke to the upper troposphere by deep convection in the equatorial region, Geophys. Res. Lett., 28, 951-954, doi:10.1029/2000GL012391, 2001.

Andreae, M. O., Jones, C. D., and Cox, P. M.: Strong present-day aerosol cooling implies a hot future, Nature, 435, 1187-1190, doi:10.1038/nature03671, 2005.

Ansmann, A., Baars, H., Tesche, M., Müller, D., Althausen, D., Engelmann, R., Pauliquevis, T., and Artaxo, P.: Dust and smoke transport from Africa to South America: Lidar profiling over Cape Verde and the Amazon rainforest, Geophys. Res. Lett., 36, L11802, doi:10.1029/2009GL037923, 2009.

Bellouin, N., Boucher, O., Haywood, J., and Reddy, M. S.: Global estimate of aerosol direct radiative forcing from satellite measurements, Nature, 438, 1138-1141, doi:10.1038/nature04348, 2005.

Ben-Ami, Y., Koren, I., Rudich, Y., Artaxo, P., Martin, S. T., and Andreae, M. O.: Transport of North African dust from the Bodélé depression to the Amazon Basin: a case study, Atmos. Chem. Phys., 10, 7533-7544, doi:10.5194/acp-10-7533-2010, 2010.

Boers, R., de Laat, A. T., Stein Zweers, D. C., and Dirksen, R. J.: Lifting potential of solar-heated aerosol layers, Geophys. Res. Lett., 37, L24802, doi:10.1029/2010GL045171, 2010.

Bond, T. C. and Bergstrom, R. W.: Light Absorption by Carbonaceous Particles: An Investigative Review, Aerosol Sci. Technol., 40, 27-67, doi:10.1080/02786820500421521, 2006.

Bond, T. C., Anderson, T. L., and Campbell, D.: Calibration and Intercomparison of Filter-Based Measurements of Visible Light Absorption by Aerosols, Aerosol Sci. Technol., 30, 582-600, doi:10.1080/027868299304435, 1999.

Bond, T. C., Streets, D. G., Yarber, K. F., Nelson, S. M., Woo, J.-H., and Klimont, Z.: A technology-based global inventory of black and organic carbon emissions from combustion, J. Geophys. Res.-Atmos., 109, D14203, doi:10.1029/2003JD003697, 2004.

Bond, T. C., Doherty, S. J., Fahey, D. W., Forster, P. M., Berntsen, T., DeAngelo, B. J., Flanner, M. G., Ghan, S., Kärcher, B., Koch, D., Kinne, S., Kondo, Y., Quinn, P. K., Sarofim, M. C., Schultz, M. G., Schulz, M., Venkataraman, C., Zhang, H., Zhang, S., Bellouin, N., Guttikunda, S. K., Hopke, P. K., Jacobson, M. Z., Kaiser, J. W., Klimont, Z., Lohmann, U., Schwarz, J. P., Shindell, D., Storelvmo, T., Warren, S. G., and Zender, C. S.: 
Bounding the role of black carbon in the climate system: A scientific assessment, J. Geophys. Res.-Atmos., 118, 5380-5552, doi:10.1002/jgrd.50171, 2013.

Brown, I. F., Schroeder, W., Setzer, A., De Los Rios Maldonado, M., Pantoja, N., Duarte, A., and Marengo, J.: Monitoring fires in southwestern Amazonia Rain Forests, Eos, Transactions American Geophysical Union, 87, 253-259, doi:10.1029/2006EO260001, 2006.

Calderón, S., Iglesias, M., Ramoni, E., Hoffmann, P., Carrillo, J., Krecji, R., Hochschild, G., Gross, J., and Jochen, G.: Variación de la concentración de ozono troposférico en la estación de investigación atmosférica "Alejandro de Humboldt" en Mérida, Venezuela, Ciencia e Ingeniería, 29, 97-106, http://erevistas. saber.ula.ve/index.php/cienciaeingenieria/article/view/248, 2008.

Chameides, W. L. and Bergin, M.: Soot Takes Center Stage, Science, 297, 2214-2215, doi:10.1126/science.1076866, 2002.

Draxler, R.: HYSPLIT4 user's guide, ERL ARL-230, Silver Spring, MD, 1999.

Edwards, D. P., Emmons, L. K., Gille, J. C., Chu, A., Attié, J.-L., Giglio, L., Wood, S. W., Haywood, J., Deeter, M. N., Massie, S. T., Ziskin, D. C., and Drummond, J. R.: Satellite-observed pollution from Southern Hemisphere biomass burning, J. Geophys. Res., 111, D14312, doi:10.1029/2005JD006655, 2006.

Forster, P., Ramaswamy, V., Artaxo, P., Berntsen, T., Betts, R., Fahey, D., Haywood, J., Lean, J., Lowe, D., Myhre, G., Nganga, J., Prinn, R., Raga, G., Schulz, M., and Dorland, R. V.: Changes in Atmospheric Constituents and in Radiative Forcing. In: Climate Change 2007: The Physical Science Basis. Contribution of Working Group I to the Fourth Assessment Report of the Intergovernmental Panel on Climate Change, Cambridge University Press, Cambridge, United Kingdom and New York, NY, USA, http://www.ipcc.ch/publications_and_data/ar4/wg1/ en/ch2.html, 2007.

Fu, H., Zhang, M., Li, W., Chen, J., Wang, L., Quan, X., and Wang, W.: Morphology, composition and mixing state of individual carbonaceous aerosol in urban Shanghai, Atmos. Chem. Phys., 12, 693-707, doi:10.5194/acp-12-693-2012, 2012.

Giannini, A., Kushnir, Y., and Cane, M. A.: Interannual Variability of Caribbean Rainfall, ENSO, and the Atlantic Ocean, J. Climate, 13, 297-311, doi:10.1175/15200442(2000)013<0297:IVOCRE>2.0.CO;2, 2000.

Giglio, L.: MODIS Collection 5 Active Fire Product User's Guide Version 2.4, Science Systems and Applications, Inc., Department of Geography, University of Maryland, College Park, MD 20742, http://maps.geog.umd.edu/firms/products/MODIS_Fire_ Users_Guide_2.4.pdf, 2010.

Giglio, L., Descloitres, J., Justice, C. O., and Kaufman, Y. J.: An Enhanced Contextual Fire Detection Algorithm for MODIS, Remote Sensing of Environment, 87, 273-282, doi:10.1016/S00344257(03)00184-6, 2003.

Giglio, L., van der Werf, G. R., Randerson, J. T., Collatz, G. J., and Kasibhatla, P.: Global estimation of burned area using MODIS active fire observations, Atmos. Chem. Phys., 6, 957974, doi:10.5194/acp-6-957-2006, 2006.

Grimm, A. M. and Tedeschi, R. G.: ENSO and Extreme Rainfall Events in South America, J. Climate, 22, 1589-1609, doi:10.1175/2008JCLI2429.1, 2009.
Häkkinen, S. A. K., Äijälä, M., Lehtipalo, K., Junninen, H., Backman, J., Virkkula, A., Nieminen, T., Vestenius, M., Hakola, H., Ehn, M., Worsnop, D. R., Kulmala, M., Petäjä, T., and Riipinen, I.: Long-term volatility measurements of submicron atmospheric aerosol in Hyytiälä, Finland, Atmos. Chem. Phys., 12, 1077110786, doi:10.5194/acp-12-10771-2012, 2012.

Hallar, A. G., Chirokova, G., McCubbin, I., Painter, T. H., Wiedinmyer, C., and Dodson, C.: Atmospheric bioaerosols transported via dust storms in the western United States, Geophys. Res. Lett., 38, L17801, doi:10.1029/2011GL048166, 2011a.

Hallar, A. G., Lowenthal, D. H., Chirokova, G., Borys, R. D., and Wiedinmyer, C.: Persistent daily new particle formation at a mountain-top location, Atmos. Environ., 45, 4111-4115, doi:10.1016/j.atmosenv.2011.04.044, 2011b.

Hao, W. M. and Liu, M.-H.: Spatial and temporal distribution of tropical biomass burning, Global Biogeochem. Cy., 8, 495-503, doi:10.1029/94GB02086, 1994.

Haywood, J. and Boucher, O.: Estimates of the direct and indirect radiative forcing due to tropospheric aerosols: A review, Rev. Geophys., 38, 513-543, doi:10.1029/1999RG000078, 2000.

Hoffmann, G.: Taking the Pulse of the Tropical Water Cycle, Science, 301, 776-777, doi:10.1126/science.1085066, 2003.

Janhäll, S., Andreae, M. O., and Pöschl, U.: Biomass burning aerosol emissions from vegetation fires: particle number and mass emission factors and size distributions, Atmos. Chem. Phys., 10, 1427-1439, doi:10.5194/acp-10-1427-2010, 2010.

Kivekäs, N., Sun, J., Zhan, M., Kerminen, V.-M., Hyvärinen, A., Komppula, M., Viisanen, Y., Hong, N., Zhang, Y., Kulmala, M., Zhang, X.-C., Deli-Geer, and Lihavainen, H.: Long term particle size distribution measurements at Mount Waliguan, a highaltitude site in inland China, Atmos. Chem. Phys., 9, 5461-5474, doi:10.5194/acp-9-5461-2009, 2009.

Koch, D., Bond, T. C., Streets, D., Unger, N., and van der Werf, G. R.: Global impacts of aerosols from particular source regions and sectors, J. Geophys. Res., 112, D02205, doi:10.1029/2005JD007024, 2007.

Koren, I., Remer, L. A., and Longo, K.: Reversal of trend of biomass burning in the Amazon, Geophys. Res. Lett., 34, L20404, doi:10.1029/2007GL031530, 2007.

Ley de Bosques y Gestión Forestal: Artículos 3,6,20,48-50 Gaceta Oficial N 38.946, Gaceta oficial de la república bolivariana de venezuela, Caracas, Venezuela, 2008.

Lohmann, U. and Feichter, J.: Global indirect aerosol effects: a review, Atmos. Chem. Phys., 5, 715-737, doi:10.5194/acp-5-7152005, 2005.

Longo, K. M., Freitas, S. R., Andreae, M. O., Yokelson, R., and Artaxo, P.: Biomass Burning in Amazonia: Emissions, Long-Range Transport of Smoke and Its Regional and Remote Impacts, 207-232, American Geophysical Union, doi:10.1029/2008GM000717, 2009.

McPhaden, M. J., Zebiak, S. E., and Glantz, M. H.: ENSO as an Integrating Concept in Earth Science, Science, 314, 1740-1745, doi:10.1126/science.1132588, 2006.

Menon, S., Hansen, J., Nazarenko, L., and Luo, Y.: Climate Effects of Black Carbon Aerosols in China and India, Science, 297, 2250-2253, doi:10.1126/science.1075159, 2002.

Mertes, S., Dippel, B., and Schwarzenböck, A.: Quantification of graphitic carbon in atmospheric aerosol particles by $\mathrm{Ra}-$ man spectroscopy and first application for the determination 
of mass absorption efficiencies, J. Aerosol Sci., 35, 347-361, doi:10.1016/j.jaerosci.2003.10.002, 2004.

Mielonen, T., Arola, A., Komppula, M., Kukkonen, J., Koskinen, J., de Leeuw, G., and Lehtinen, K. E. J.: Comparison of CALIOP level 2 aerosol subtypes to aerosol types derived from AERONET inversion data, Geophys. Res. Lett., 36, L18804, doi:10.1029/2009GL039609, 2009.

Morales, J., Hermoso, M., Serrano, J., and Sanhueza, E.: Trace elements in the Venezuelan savannah atmosphere during dry and wet periods, with and without vegetation burning, Atmos. Environ. A., 24, 407-414, doi:10.1016/0960-1686(90)90121-3, 1990.

Myhre, G.: Consistency Between Satellite-Derived and Modeled Estimates of the Direct Aerosol Effect, Science, 325, 187-190, doi:10.1126/science.1174461, 2009.

Naoe, H., Hasegawa, S., Heintzenberg, J., Okada, K., Uchiyama, A., Zaizen, Y., Kobayashi, E., and Yamazaki, A.: State of mixture of atmospheric submicrometer black carbon particles and its effect on particulate light absorption, Atmos. Environ., 43, 1296-1301, doi:10.1016/j.atmosenv.2008.11.031, 2009.

Novakov, T., Ramanathan, V., Hansen, J. E., Kirchstetter, T. W., Sato, M., Sinton, J. E., and Sathaye, J. A.: Large historical changes of fossil-fuel black carbon aerosols, Geophys. Res. Lett., 30, 1324, doi:10.1029/2002GL016345, 2003.

Omar, A. H., Winker, D. M., Vaughan, M. A., Hu, Y., Trepte, C. R., Ferrare, R. A., Lee, K.-P., Hostetler, C. A., Kittaka, C., Rogers, R. R., Kuehn, R. E., and Liu, Z.: The CALIPSO Automated Aerosol Classification and Lidar Ratio Selection Algorithm, J. Atmos. Oceanic Technol., 26, 1994-2014, doi:10.1175/2009JTECHA1231.1, 2009.

Pratt, K. A., Murphy, S. M., Subramanian, R., DeMott, P. J., Kok, G. L., Campos, T., Rogers, D. C., Prenni, A. J., Heymsfield, A. J., Seinfeld, J. H., and Prather, K. A.: Flight-based chemical characterization of biomass burning aerosols within two prescribed burn smoke plumes, Atmos. Chem. Phys., 11, 1254912565, doi:10.5194/acp-11-12549-2011, 2011.

Ramanathan, V. and Carmichael, G.: Global and regional climate changes due to black carbon, Nature Geosci, 1, 221-227, doi:10.1038/ngeo156, 2008.

Ramanathan, V., Ramana, M. V., Roberts, G., Kim, D., Corrigan, C., Chung, C., and Winker, D.: Warming trends in Asia amplified by brown cloud solar absorption, Nature, 448, 575-578, doi:10.1038/nature06019, 2007.

Reid, J. S., Koppmann, R., Eck, T. F., and Eleuterio, D. P.: A review of biomass burning emissions part II: intensive physical properties of biomass burning particles, Atmos. Chem. Phys., 5, 799825, doi:10.5194/acp-5-799-2005, 2005.

Rissler, J., Vestin, A., Swietlicki, E., Fisch, G., Zhou, J., Artaxo, P., and Andreae, M. O.: Size distribution and hygroscopic properties of aerosol particles from dry-season biomass burning in Amazonia, Atmos. Chem. Phys., 6, 471-491, doi:10.5194/acp6-471-2006, 2006.

Rizzo, L. V., Artaxo, P., Müller, T., Wiedensohler, A., Paixão, M., Cirino, G. G., Arana, A., Swietlicki, E., Roldin, P., Fors, E. O., Wiedemann, K. T., Leal, L. S. M., and Kulmala, M.: Long term measurements of aerosol optical properties at a primary forest site in Amazonia, Atmos. Chem. Phys., 13, 2391-2413, doi:10.5194/acp-13-2391-2013, 2013.
Rondón, A. and Sanhueza, E.: Seasonal variation of gaseous HNO3 and NH3 at a Tropical Savannah site, J. Atmos. Chem., 11, 245254, doi:10.1007/BF00118351, 1990.

Roy, D., Jin, Y., Lewis, P., and Justice, C.: Prototyping a global algorithm for systematic fire-affected area mapping using MODIS time series data, Remote Sens. Environ., 97, 137-162, doi:10.1016/j.rse.2005.04.007, 2005.

Roy, D., Boschetti, L., Justice, C., and Ju, J.: The collection 5 MODIS burned area product - Global evaluation by comparison with the MODIS active fire product, Remote Sens. Environ., 112, 3690-3707, doi:10.1016/j.rse.2008.05.013, 2008.

Sakaeda, N., Wood, R., and Rasch, P. J.: Direct and semidirect aerosol effects of southern African biomass burning aerosol, J. Geophys. Res., 116, D12205, doi:10.1029/2010JD015540, 2011.

Sanhueza, E., Rondón, A., and Romero, J.: Airborne particles in the Venezuelan savannah during burning and non-burning periods, Atmos. Environ., 21, 2227-2231, doi:10.1016/00046981(87)90354-4, 1987.

Sanhueza, E., Crutzen, P. J., and Fernández, E.: Production of boundary layer ozone from tropical American Savannah biomass burning emissions, Atmos. Environ., 33, 4969-4975, doi:10.1016/S1352-2310(99)00301-5, 1999.

Schmeissner, T., Krejci, R., Ström, J., Birmili, W., Wiedensohler, A., Hochschild, G., Gross, J., Hoffmann, P., and Calderon, S.: Analysis of number size distributions of tropical free tropospheric aerosol particles observed at Pico Espejo (4765 $\mathrm{m}$ a.s.1.), Venezuela, Atmos. Chem. Phys., 11, 3319-3332, doi:10.5194/acp-11-3319-2011, 2011.

Schwarz, J. P., Gao, R. S., Spackman, J. R., Watts, L. A., Thomson, D. S., Fahey, D. W., Ryerson, T. B., Peischl, J., Holloway, J. S., Trainer, M., Frost, G. J., Baynard, T., Lack, D. A., de Gouw, J. A., Warneke, C., and Del Negro, L. A.: Measurement of the mixing state, mass, and optical size of individual black carbon particles in urban and biomass burning emissions, Geophys. Res. Lett., 35, L13810, doi:10.1029/2008GL033968, 2008.

Shindell, D. T., Faluvegi, G., Koch, D. M., Schmidt, G. A., Unger, N., and Bauer, S. E.: Improved Attribution of Climate Forcing to Emissions, Science, 326, 716-718, doi:10.1126/science.1174760, 2009.

Shindell, D., Kuylenstierna, J. C. I., Vignati, E., van Dingenen, R., Amann, M., Klimont, Z., Anenberg, S. C., Muller, N., Janssens-Maenhout, G., Raes, F., Schwartz, J., Faluvegi, G., Pozzoli, L., Kupiainen, K., Höglund-Isaksson, L., Emberson, L., Streets, D., Ramanathan, V., Hicks, K., Oanh, N. T. K., Milly, G., Williams, M., Demkine, V., and Fowler, D.: Simultaneously Mitigating Near-Term Climate Change and Improving Human Health and Food Security, Science, 335, 183-189, doi:10.1126/science.1210026, 2012.

Stohl, A., Forster, C., Frank, A., Seibert, P., and Wotawa, G.: Technical note: The Lagrangian particle dispersion model FLEXPART version 6.2, Atmos. Chem. Phys., 5, 2461-2474, doi:10.5194/acp-5-2461-2005, 2005.

Streets, D. G., Bond, T. C., Lee, T., and Jang, C.: On the future of carbonaceous aerosol emissions, J. Geophys. Res., 109, D24212, doi:10.1029/2004JD004902, 2004.

Ten Hoeve, J. E., Jacobson, M. Z., and Remer, L. A.: Comparing results from a physical model with satellite and in situ observations to determine whether biomass burning aerosols over the Ama- 
zon brighten or burn off clouds, J. Geophys. Res., 117, D08203, doi:10.1029/2011JD016856, 2012.

Torres, O., Chen, Z., Jethva, H., Ahn, C., Freitas, S. R., and Bhartia, P. K.: OMI and MODIS observations of the anomalous 20082009 Southern Hemisphere biomass burning seasons, Atmos. Chem. Phys., 10, 3505-3513, doi:10.5194/acp-10-3505-2010, 2010.

van der Werf, G. R., Randerson, J. T., Collatz, G. J., Giglio, L., Kasibhatla, P. S., Arellano, A. F., Olsen, S. C., and Kasischke, E. S.: Continental-Scale Partitioning of Fire Emissions During the 1997 to 2001 El Niño/La Niña Period, Science, 303, 73-76, doi:10.1126/science.1090753, 2004.

van Poppel, L. H., Friedrich, H., Spinsby, J., Chung, S. H., Seinfeld, J. H., and Buseck, P. R.: Electron tomography of nanoparticle clusters: Implications for atmospheric lifetimes and radiative forcing of soot, Geophys. Res. Lett., 32, L24811, doi:10.1029/2005GL024461, 2005.

VanCuren, R. A., Cliff, S. S., Perry, K. D., and Jimenez-Cruz, M.: Asian continental aerosol persistence above the marine boundary layer over the eastern North Pacific: Continuous aerosol measurements from Intercontinental Transport and Chemical Transformation 2002 (ITCT 2K2), J. Geophys. Res.-Atmos., 110, D09S90, doi:10.1029/2004JD004973, 2005.

Venzac, H., Sellegri, K., Laj, P., Villani, P., Bonasoni, P., Marinoni, A., Cristofanelli, P., Calzolari, F., Fuzzi, S., Decesari, S., Facchini, M.-C., Vuillermoz, E., and Verza, G. P.: High frequency new particle formation in the Himalayas, P. Natl. Acad. Sci., 105, 15666-15671, doi:10.1073/pnas.0801355105, 2008.

Virkkula, A.: Correction of the Calibration of the 3-wavelength Particle Soot Absorption Photometer (3 $\lambda$ PSAP), Aerosol Sci. Technol., 44, 706-712, doi:10.1080/02786826.2010.482110, 2010.

Virkkula, A., Ahlquist, N. C., Covert, D. S., Arnott, W. P., Sheridan, P. J., Quinn, P. K., and Coffman, D. J.: Modification, Calibration and a Field Test of an Instrument for Measuring Light Absorption by Particles, Aerosol Sci. Technol., 39, 68-83, doi:10.1080/027868290901963, 2005.

Wehner, B., Petäjä, T., Boy, M., Engler, C., Birmili, W., Tuch, T., Wiedensohler, A., and Kulmala, M.: The contribution of sulfuric acid and non-volatile compounds on the growth of freshly formed atmospheric aerosols, Geophys. Res. Lett., 32, L17810, doi:10.1029/2005GL023827, 2005.
Weingartner, E., Nyeki, S., and Baltensperger, U.: Seasonal and diurnal variation of aerosol size distributions $(10<\mathrm{D}<750 \mathrm{~nm})$ at a high-alpine site (Jungfraujoch $3580 \mathrm{~m}$ asl), J. Geophys. Res.Atmos., 104, 26809-26820, doi:10.1029/1999JD900170, 1999.

Wiedensohler, A., Birmili, W., Nowak, A., Sonntag, A., Weinhold, K., Merkel, M., Wehner, B., Tuch, T., Pfeifer, S., Fiebig, M., Fjäraa, A. M., Asmi, E., Sellegri, K., Depuy, R., Venzac, H., Villani, P., Laj, P., Aalto, P., Ogren, J. A., Swietlicki, E., Williams, P., Roldin, P., Quincey, P., Hüglin, C., Fierz-Schmidhauser, R., Gysel, M., Weingartner, E., Riccobono, F., Santos, S., Grüning, C., Faloon, K., Beddows, D., Harrison, R., Monahan, C., Jennings, S. G., O’Dowd, C. D., Marinoni, A., Horn, H.-G., Keck, L., Jiang, J., Scheckman, J., McMurry, P. H., Deng, Z., Zhao, C. S., Moerman, M., Henzing, B., de Leeuw, G., Löschau, G., and Bastian, S.: Mobility particle size spectrometers: harmonization of technical standards and data structure to facilitate high quality long-term observations of atmospheric particle number size distributions, Atmos. Meas. Tech., 5, 657-685, doi:10.5194/amt5-657-2012, 2012.

Winker, D. M., Vaughan, M. A., Omar, A., Hu, Y., Powell, K. A., Liu, Z., Hunt, W. H., and Young, S. A.: Overview of the CALIPSO Mission and CALIOP Data Processing Algorithms, J. Atmos. Oceanic Technol., 26, 2310-2323, doi:10.1175/2009JTECHA1281.1, 2009.

Yang, M., Howell, S. G., Zhuang, J., and Huebert, B. J.: Attribution of aerosol light absorption to black carbon, brown carbon, and dust in China - interpretations of atmospheric measurements during EAST-AIRE, Atmos. Chem. Phys., 9, 2035-2050, doi:10.5194/acp-9-2035-2009, 2009.

Zhang, R., Khalizov, A. F., Pagels, J., Zhang, D., Xue, H., and McMurry, P. H.: Variability in morphology, hygroscopicity, and optical properties of soot aerosols during atmospheric processing, P. Natl. Acad. Sci., 105, 10291-10296, doi:10.1073/pnas.0804860105, 2008. 